\title{
Formation evaluation and reservoir characteristics of the Messinian Abu Madi sandstones in Faraskour Gas Field, onshore Nile Delta, Egypt
}

\author{
Mahmoud Leila $^{1}$ - $\cdot$ Ali Eslam $^{1} \cdot$ Asmaa Abu El-Magd $^{1} \cdot$ Lobna Alwaan $^{1} \cdot$ Ahmed Elgendy $^{1}$
}

Received: 6 August 2020 / Accepted: 19 September 2020 / Published online: 10 October 2020

(c) The Author(s) 2020

\begin{abstract}
The Messinian Abu Madi Formation represents the most prospective reservoir target in the Nile Delta. Hydrocarbon exploration endeavors in Nile Delta over the last few decades highlighted some uncertainties related to the predictability and distribution of the Abu Madi best reservoir quality facies. Therefore, this study aims at delineating the factors controlling the petrophysical heterogeneity of the Abu Madi reservoir facies in Faraskour Field, northeastern onshore part of the Nile Delta. This work provides the very first investigation on the reservoir properties of Abu Madi succession outside the main canyon system. In the study area, Abu Madi reservoir is subdivided into two sandstone units (lower fluvial and upper estuarine). Compositionally, quartzose sandstones (quartz $>65 \%$ ) are more common in the fluvial unit, whereas the estuarine sandstones are often argillaceous (clays $>15 \%$ ) and glauconitic (glauconite $>10 \%$ ). The sandstones were classified into four reservoir rock types (RRTI, RRTII, RRTIII, and RRTIV) having different petrophysical characteristics and fluid flow properties. RRTI hosts the quartzose sandstones characterized by mega pore spaces $\left(R_{35}>45 \mu \mathrm{m}\right)$ and a very well-connected, isotropic pore system. On the other side, RRTIV constitutes the lowest reservoir quality argillaceous sandstones containing meso- and micro-sized pores $\left(R_{35}>5 \mu \mathrm{m}\right)$ and a pore system dominated by dead ends. Irreducible water saturation increases steadily from RRTI $\left(S_{\text {wir }} \sim 5 \%\right)$ to RRTIV $\left(S_{\text {wir }}>20 \%\right)$. Additionally, the gas-water two-phase co-flowing characteristics decrease significantly from RRTI to RRTIV facies. The gaseous hydrocarbons will be able to flow in RRTI facies even at water saturation values exceeding $90 \%$. On the other side, the gas will not be able to displace water in RRTIV sandstones even at water saturation values as low as $40 \%$. Similarly, the influence of confining pressure on porosity and permeability destruction significantly increases from RRTI to RRTIV. Accordingly, RRTI facies are the best reservoir targets and have high potentiality for primary porosity preservation.
\end{abstract}

Keywords Messinian $\cdot$ Abu Madi $\cdot$ Nile Delta $\cdot$ Reservoir $\cdot$ Petrophysics $\cdot$ Reservoir rock typing

\section{Introduction}

The Nile Delta with its recent giant onshore and offshore gas discoveries (e.g., Zohr, Noras) is currently proven as the most prolific gas province in North Africa (e.g., Esestime et al. 2016). The main reservoir targets in the Nile Delta range in age from Oligocene to Late Pliocene. The occurrence of many mature source rocks (Jurassic to Early Miocene), as well as the availability of structural and stratigraphic traps, enhanced the potentiality for prospective hydrocarbon accumulations in the Nile Delta (EGPC 1994;

Mahmoud Leila

Mahmoud_lotfy@mans.edu.eg

1 Geology Department, Faculty of Science, Mansoura University, Mansoura City, Egypt
Abdel Aal et al. 1994; Dolson et al. 2005). The thermogenic gas, condensate and light oil accumulations in the Nile Delta were mainly sourced from the Jurassic and upper Cretaceous-lower Paleogene source rock intervals (e.g., Vandre et al. 2007; Leila and Moscariello 2017; El-Diasty et al. 2020). On the other hand, the clay-rich successions of the Kafr El-Sheikh Formation constitute the main source of biogenic gases in the Nile Delta onshore region (Vandre et al. 2007). Offshore Nile Delta, the Miocene (Tineh, Qantara, Sidi Salem and Wakar) and Pliocene (Kafr El-Sheikh) shales are proven sources for the biogenic gases (Vandre et al. 2007; Esestime et al. 2016).

The Upper Messinian succession of the Nile Delta (Abu Madi Formation) constitutes a variety of depositional facies (fluvial and estuarine) which constitutes the main hydrocarbon exploration targets, particularly in the

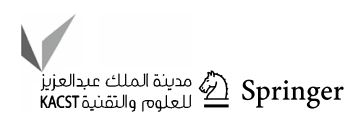


onshore region (Dolson et al. 2001; Salem et al. 2005; Leila et al. 2016, 2020). The quality of the Abu Madi reservoir facies is largely controlled by their initial depositional conditions, whereas the post-depositional attributes play a relatively minor role (Salem et al. 2005; Leila et al. 2019; Leila and Moscariello 2019). Despite their importance hosting the majority of gas reserves in the onshore Nile delta, a detailed rock typing of the Abu Madi sediments as well as accurate identification of their flow properties and the predictability of their spatial distribution and architecture have never been performed. Therefore, the present study will tackle these issues through comprehensive integration between seismic, petrography, as well as routine and special core analyses. Moreover, this study will focus for the first time on Abu Madi system in the extreme northeastern margins of the Nile Delta outside the Abu Madi main canyon play (Fig. 1). This study will enhance the predictability of the Abu Madi reservoir performance which will direct the development strategies in the study area.

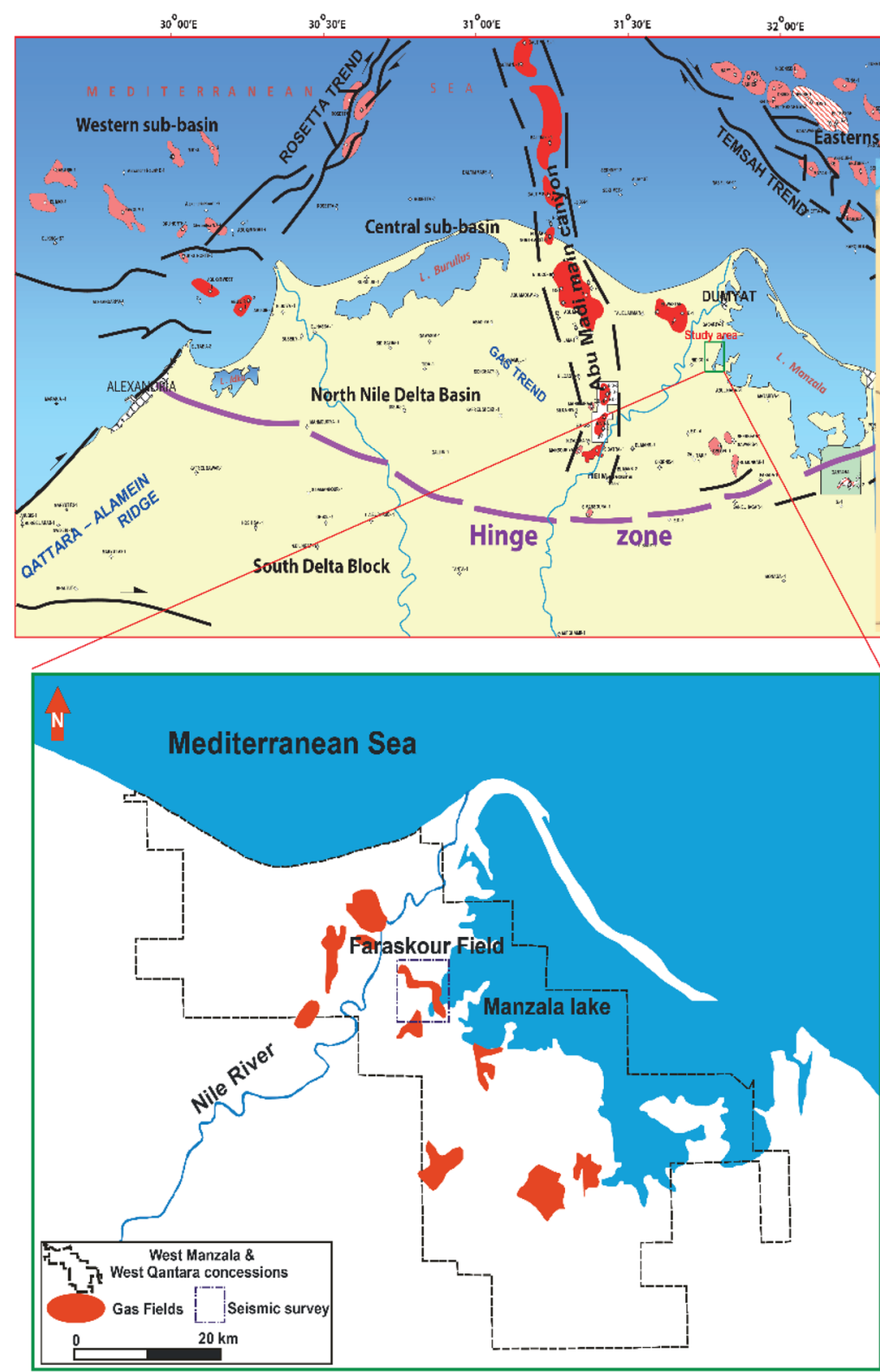

${ }_{32}{ }^{\circ} 30 \mathbf{E}$ 


\section{Geologic setting}

The Nile Delta was initially developed during the Late Eocene-Early Miocene times in an area very close to the Qattara Depression and suddenly moved to its present position during Late Miocene (Salem 1976; Said 1990; Sestini 1995). The tectonic history of the Nile Delta comprised five main stages from the cratonic phase after the Caledonian-Hercynian Orogeny, rift phase (Triassic), passive margin phase (Jurassic-Early Cretaceous), Alpine compressional phase (Late Cretaceous-Eocene), and then a foreland phase during Late Eocene and Oligocene (EGPC 1994). These phases controlled not only the structural and depositional evolution but also the hydrocarbon prospectivity of the Nile Delta (Meshref 1990; Sarhan and Hemdan 1994; Abdel Aal et al. 1994; Kamel et al. 1998). Currently, the Nile Delta presents a passive margin basin in northeastern part of the African continental margin (Dixon and Robertson 1984; Sarhan and Hemdan 1994). The rifting phase of the Tethyan margin and the opening of the Mediterranean resulted in an E-W flexure zone "Hinge Zone" which controlled the Paleogene-Neogene tectono-stratigraphic evolution of the Nile Delta (Fig. 1; Orwig 1982; Harms and Wray 1990; Kamel et al. 1998). The Hinge Zone represents the boundary between the platformal carbonates of the south delta block and the north Nile Delta basinal facies (Sarhan and Hemdan 1994; Kamel et al. 1998).

Shallow-water carbonate sedimentation predominates the Nile Delta during the Jurassic up to Early Cretaceous (Bayoumi and Lotfy 1989; Guiraud and Bosworth 1999). Open marine conditions prevailed during Early Cretaceous, and by the end of the Aptian alternating shallowwater and alluvial sedimentation prevailed in the Nile Delta (Guiraud and Bosworth 1999). During Paleogene, continental sedimentation prevailed subsequent to the onset of the Gulf of Suez rifting phase and the northward tilting of the Nile Delta toward the Mediterranean (Rizzini et al. 1978; Sarhan and Hemdan 1994; Hussein and Abd-Allah 2001; Dolson et al. 2005). Early Miocene was marked by major marine transgression and deposition of thick marine shales and basinal marls (Burdigalian, Qantara Formation). Shallow marine sedimentation predominates the Nile Delta during Serravallian; the high subsidence rates and elevated sediment influx resulted in deposition of thick shallow marine shales interbedded with dolomitic marls and lenticular sandstones (Sidi Salem Formation) (Fig. 2; Rizzini et al. 1978; Kamel et al. 1998; Dolson et al. 2005). Regressive phase prevailed in the Nile Delta during Tortonian-Early Messinian, and prograding deltaic sedimentation predominates in the onshore regions (Qawasim Formation). Synchronously, deposition of turbiditic complexes predominates in the Nile Delta offshore parts (Wakar Formation). By the end of Miocene, the Mediterranean was partially or completely desiccated during the Messinian salinity crisis (MSC) (Hsü et al. 1973). Subsequently, deep subaerial canyons were incised along the Mediterranean margins and thick marginal and abyssal evaporites were accumulated in the basins. These canyons are poorly documented along the North African margin except in the Nile Delta where the large Eonile canyon is well known from both onshore and offshore regions (e.g., Barber 1981; Palmieri et al. 1996; Dalla et al. 1997; Dolson et al. 2001, 2005; Leila and Moscariello 2019; Leila et al. 2020). An incipient sea-level rise during the late stage of the MSC results in a backstepping infill of the Eonile canyon by fluvial and estuarine sandstones (Abu Madi Formation) (Palmieri et al. 1996; Dalla et al. 1997; Dolson et al. 2001, 2005; Leila and Moscariello 2019).

\section{Data and methods}

The present study is based on a complete subsurface dataset (seismic, logs and cores) from Faraskour field. The dataset was analyzed and interpreted following a stepwise procedure in order to achieve the study objectives (Fig. 3).

\section{Seismic interpretation}

Seismic interpretation comprises detailed analyses of the available 2D reflection seismic profiles covering the study area (Fig. 1). This constitutes a proper identification of the seismic sequence boundaries bounding the Messinian Abu Madi succession. Moreover, the internal seismic facies encountered within the Abu Madi succession were described by tracking the different reflection configurations and stratal terminations (e.g., Vail et al. 1977; Pigott and Radivojevic 2010).

\section{Sandstone petrography}

Petrographic analyses involved the examination of 18 thin sections from the Abu Madi sandstones in Faraskour-4 well using the petrographic microscope under plane polarized light. Thin sections preparation was conducted at Corex Laboratories, Egypt. The thin sections were stained with blue dye for porosity visualization as well as Alizarin Red-S and K-ferricyanide to identify the different carbonate phases. Sodium cobalt nitrate dye was utilized to facilitate the identification of feldspar (e.g., Houghton 1980).

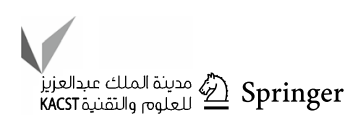




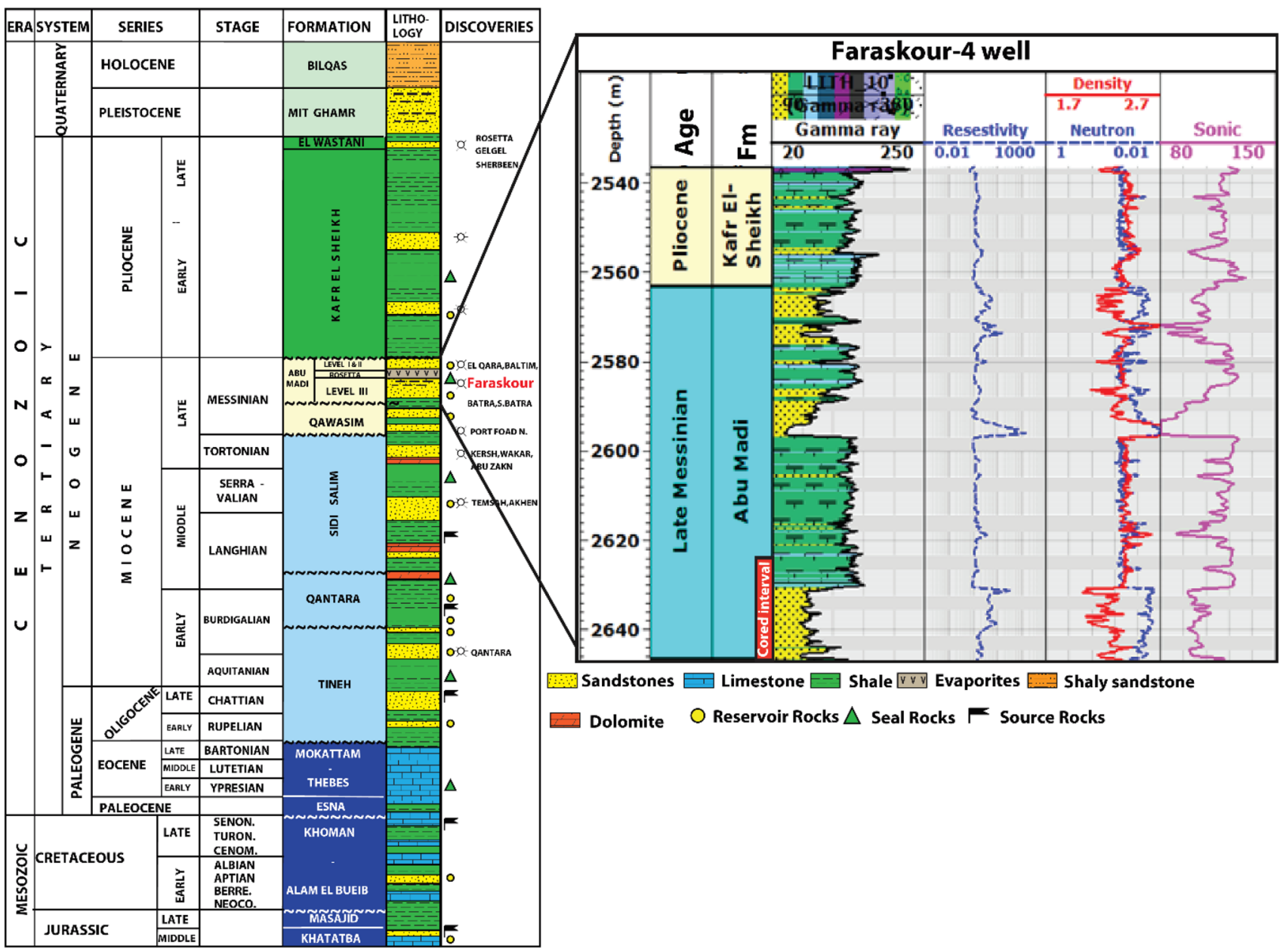

Fig. 2 Generalized lithostratigraphic column of the study area correlated with the drilled Messinian succession in Fraskour-4 well (modified after Corex 2007)

\section{Petrophysical analyses}

The different petrophysical parameters (porosity, permeability and fluid saturations) were calculated for the entire Abu Madi Formation using a complete conventional wireline log data retrieved from Faraskour-4 well. Effective porosity was determined from porosity logs and was corrected for the gas effect within the gas-bearing zones following the procedure described by Schlumberger (1974). Water saturation and subsequently hydrocarbon saturation in the uninvaded zone were estimated using Archie's equation (1942). Moreover, the permeability values were calculated as a function of the irreducible water saturation and effective porosity using Timur equation (Timur 1968).

Conventional core analyses (CCA) include porosity, permeability and grain density measurements. These were performed at the Egyptian Petroleum Research Institute (EPRI), Egypt, on a total of 18 conventional core plugs selected from the Messinian Abu Madi succession in Faraskour-4 well (Fig. 2).
The porosity and permeability values were measured using helium gas expansion porosimeter and nitrogen permeameter, respectively, under ambient pressure conditions. Distribution of the measured porosity and permeability values is presented in Fig. 4. In this study, the concept of the hydraulic flow unit proposed by Amaefule et al. (1993) was applied to evaluate the hydraulic flow properties of the Abu Madi Formation. The proposed hydraulic flow parameters which include the reservoir quality index (RQI), normalized porosity index (NPI) and flow zone indicator (FZI) are used in the classification of the Abu Madi Formation into reservoir rock types (RRT). The applied parameters were calculated as follows:

$\mathrm{RQI}=0.0314 \sqrt{K / \Phi}$

$\mathrm{NPI}=\frac{\Phi}{1-\Phi}$ 


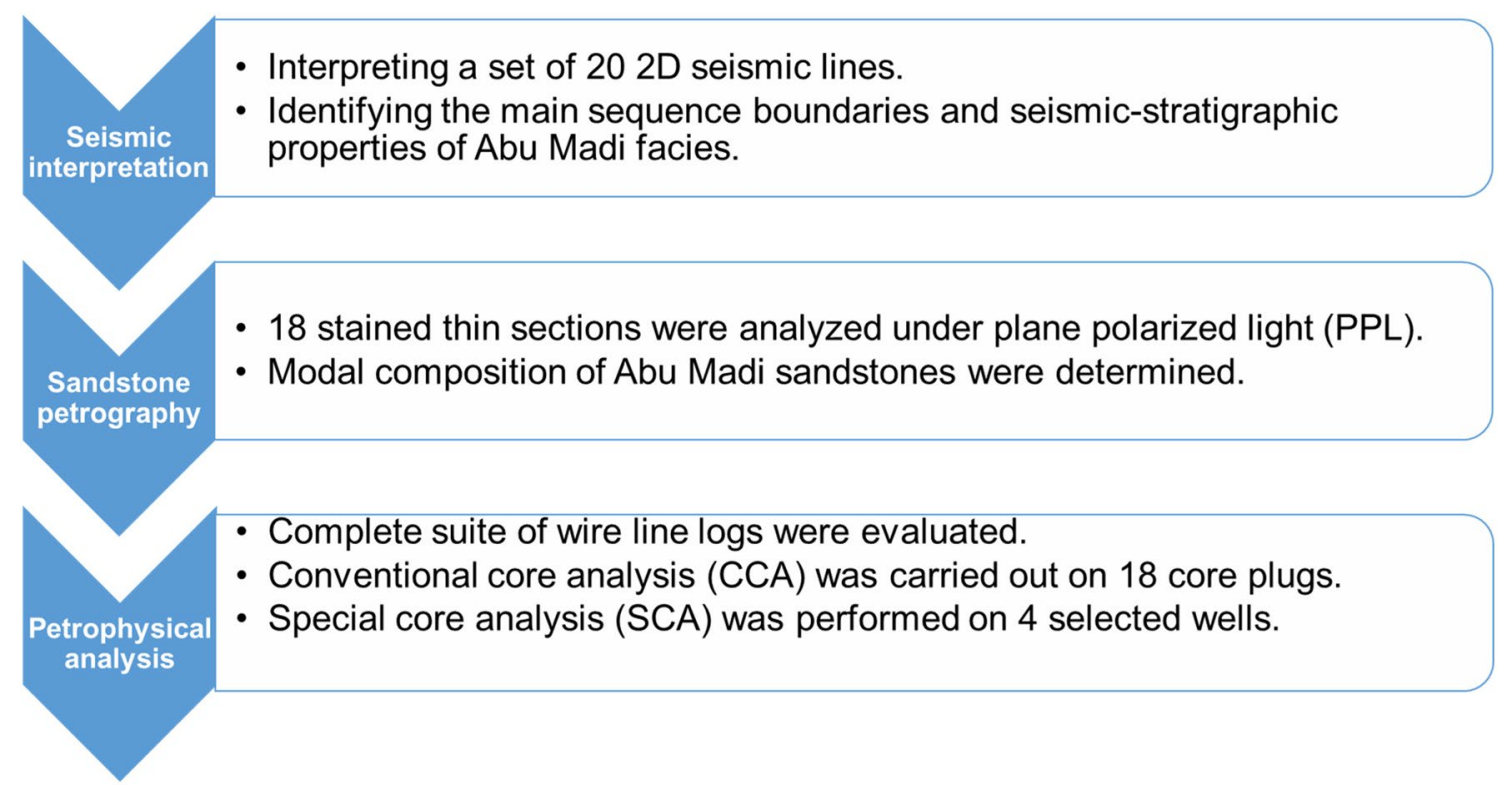

Fig. 3 Illustrative flowchart shows the stepwise procedure followed in this study for data analysis and interpretation

$$
\mathrm{FZI}=\frac{\mathrm{RQI}}{\mathrm{NPI}}
$$

Moreover, the pore throat radius was calculated using the equation proposed by Kolodzie (1980) as follows:

$R_{35}=5.395 \frac{K^{0.588}}{\Phi^{0.824}}$

The special core analyses (SCA) involve porosity and permeability measurements under confining pressure conditions by applying an effective overburden pressure of 4700 , 5700 and 6700 psi. This was carried out on four core plug samples by mounting the samples in a hydraulic core holder after saturation with synthetic formation water. Each sample was then loaded into triaxial core holder. A pipette was connected to the end stem of each core holder. The confining stress was raised incrementally, and the reduction in the pore volume was monitored as an increase in the pipette readings.

\section{Results}

\section{Abu Madi seismic and sedimentary facies}

The Messinian succession is bounded by two seismic sequence boundaries (Figs. 5a, 6a). The lower is distinguished by the erosional truncation terminations in which the pre-MSC seismic reflections were abruptly terminated against the overlying unconformity surface. This seismic unconformity is represented by high-amplitude, irregular reflection displaying highly erosive, wide $\mathrm{U}$ - and $\mathrm{V}$-shaped incised depressions which are commonly onlapped and infilled by MSC Abu Madi facies. The stratigraphic position of this unconformity, its morphology and seismic-stratigraphic characteristics coincide with the bottom erosion surface (BES) which documents the boundary between the pre-MSC and syn-, post-MSC facies along the entire Mediterranean (Lofi et al. 2011a, b; Pigott and Abdel-Fattah 2014; Leila and Moscariello 2019). The U- and V-shaped depressions represent the subaerial canyons incised during the MSC in the study area (e.g., Barber 1981; Dolson et al. 2001; Leila and Moscariello 2019). The BES is onlapped by vertically variable amplitude seismic reflections which comprise the syn-MSC Abu Madi facies that infilled the subaerial canyons during the late intra-Messinian transgression. The upper sequence boundary consists of semi-horizontal, high-amplitude, continuous seismic reflector. This boundary is marked by a strong acoustic contrast between the underlying MSC and overlying post-MSC facies. This seismic boundary corresponds to the top erosion surface (TES) which marks the end of the MSC event in the entire Mediterranean (e.g., Clauzon et al. 1995; Lofi et al. 2005).

Paving the canyon floor, low-amplitude, semitransparent and semi-chaotic seismic reflections (Fig. 3a) occur and likely correspond to the high-energy subaerial gravity flow deposits synchronously accumulated during the canyon incision (e.g., Leila and Moscariello 2019). These lowamplitude, transparent facies are followed by two parallel, continuous and high-amplitude reflectors (Figs. 5b, 6b). The extracted root-mean-square (RMS) amplitude map along the lower reflector (@2350 ms ms) highlights high-amplitude anomalies distributed in NW-SE oriented channels

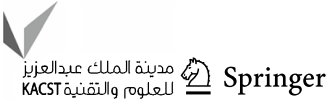


Fig. 4 Histograms illustrating the variation in the measured porosity and permeability values
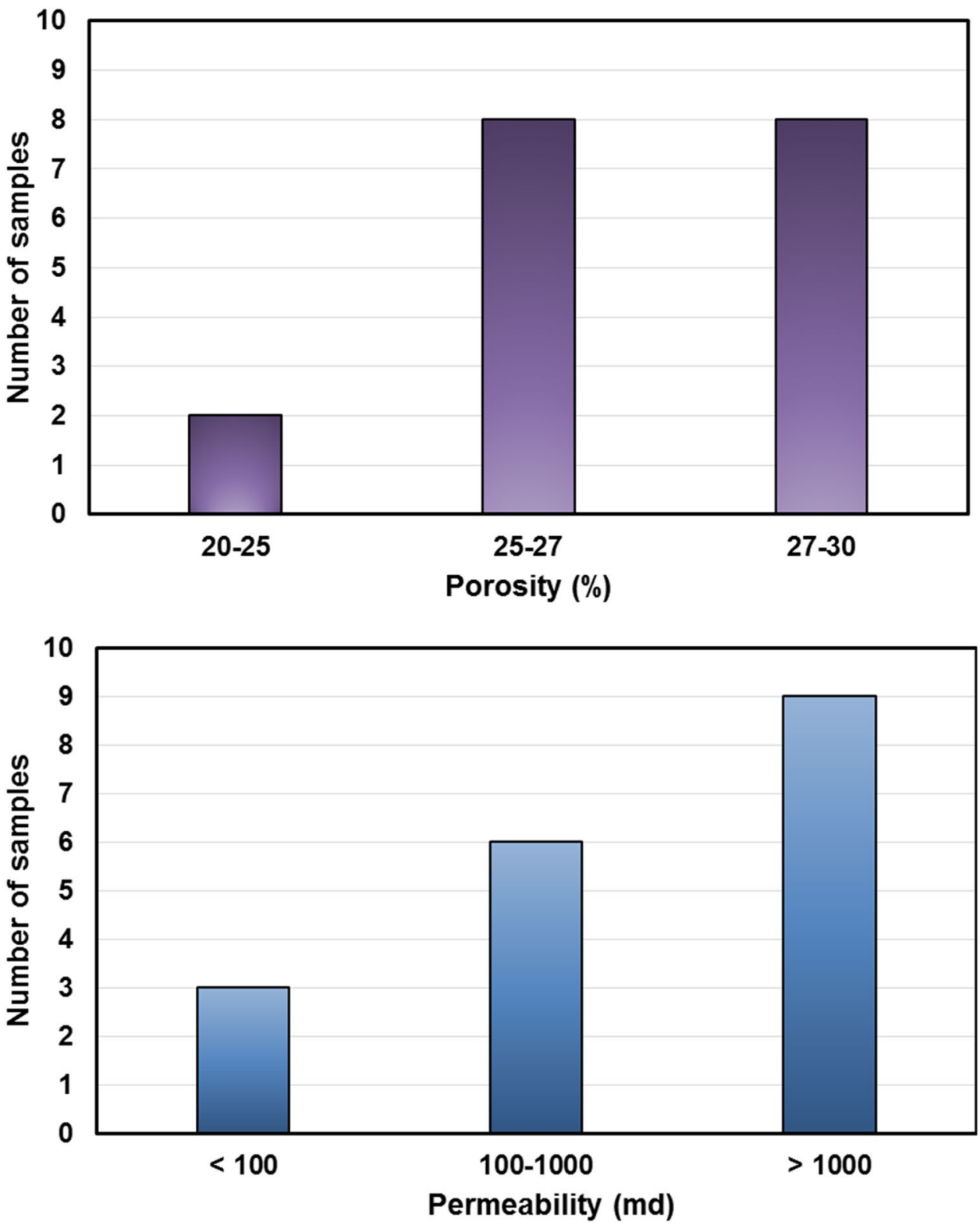

(Fig. 7a). Additionally, the RMS amplitude map along the upper reflector (@2320 ms) illustrates NW-SE oriented small high-amplitude bars (Fig. 7b). The gamma ray counts corresponding the NW-SE oriented channels are generally low (<55 API) reflecting a clean sandy composition. Moreover, the blocky-shaped gamma ray motif having a sharp base suggests in-channel deposition (Fig. 7c). The basal part of this interval is characterized by an upward decrease in the gamma ray values, revealing a coarsening upward succession likely reflecting the amalgamation of the channel sand bars. This is followed by a bell-shaped fining-upward gamma ray pattern having comparatively elevated gamma ray counts (>80 API) suggesting an upward increase in the argillaceous materials. This is consistent with the core observations as the channel bars sandstones consist of coarse-grained massive sandstone and planar cross-stratified sandstones grade upward into fine-grained, parallel laminated argillaceous sandstone (Fig. 7c). The occurrence of dewatering features and dish structures suggest deposition under high-energy conditions (e.g., Miall 1996; Tucker 2001). This depositional pattern corresponds to the backstepping fluvial channel-fill facies that were accumulated during the late stage of the MSC (e.g., Palmieri et al. 1996; Dolson et al. 2001; Leila and Moscariello 2019). The upward decrease in grain size, increase in mud content and appearance of lamination suggest a gradual decrease in the flow energy and possibly the transition from pure fluvial to mixed energy depositional conditions consistent with the upward reversal of the gamma ray log motif (e.g., Terwindt 1971; Van den berg et al. 2007). 

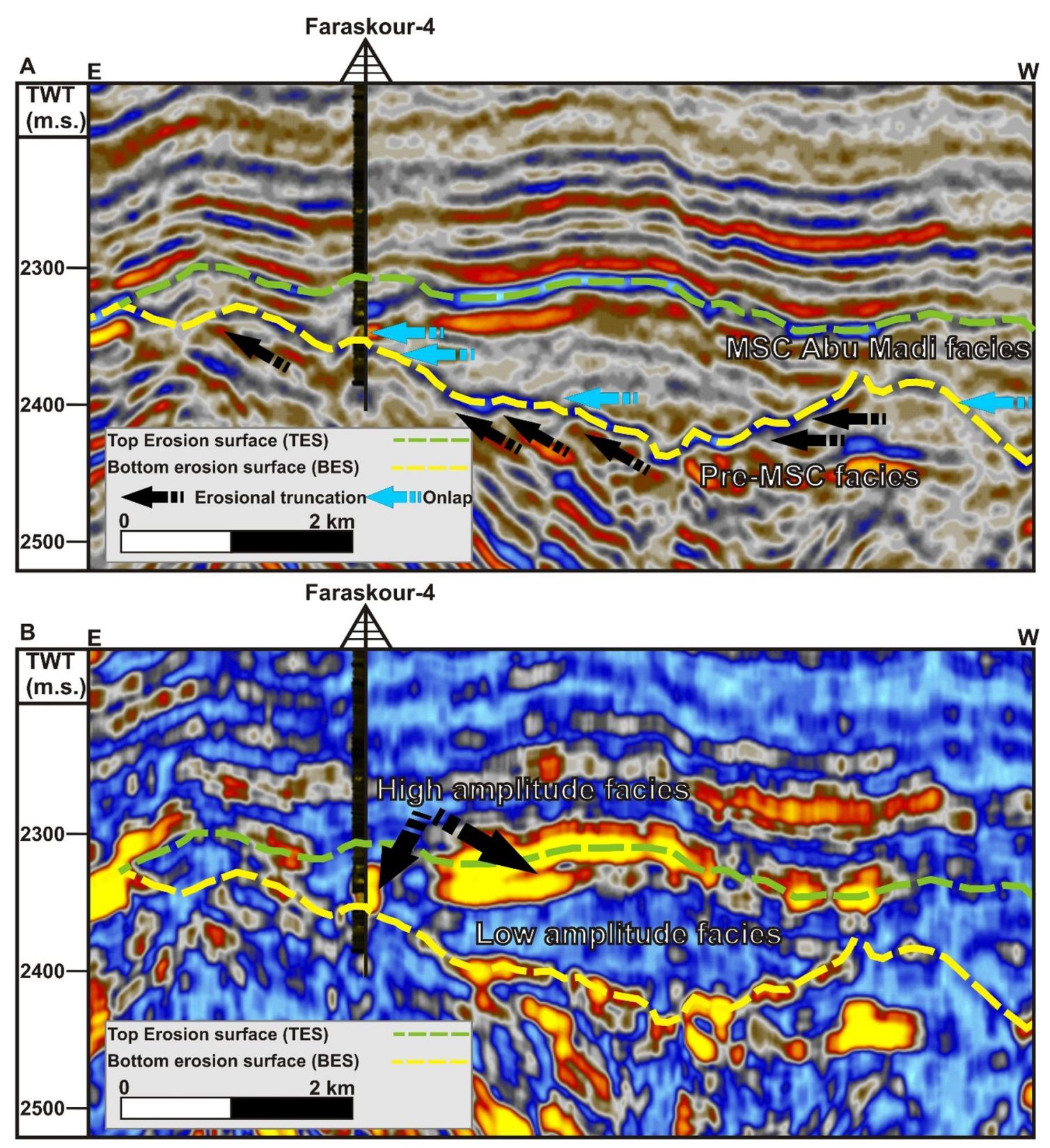

Fig. 5 Interpreted E-W seismic section in original amplitude (a) and RMS amplitude attribute (b) illustrating the Abu canyon and its MSC-infill facies (see location in Fig. 1)

The sedimentary facies of the Abu Madi upper reflector consist of mudstone/siltstone facies $(\sim 35 \mathrm{~m})$ which cap the sandstone interval and consist of massive and laminated mudstones interbedded with siltstones. Planar pinstripe laminae, tidal bundles and mud drapes are the main observed sedimentary structures (Fig. 7c). These muddy-rich facies were mostly deposited in a tidal flat environment and record the complete transition from fluvial to tidal-dominated conditions (e.g., Klein 1971; Buatois et al. 1999; Leila and Moscariello 2019). The mudstone facies are followed by finingupward sandstones (11 m thick) which likely represent the tidal channel-fill facies overlain by 13 -m-thick argillaceous sandstone interval corresponding to the tidal sand bar facies consistent with seismic observations (Fig. 8b). These facies represent the transgressive estuarine sediments deposited during the late MSC incipient sea-level rise (Lago Mare phase, Dabrio and Polo 1995; Krijgsman et al. 2001).

\section{Abu Madi sandstones' composition}

Petrographic investigation reveals that the Abu Madi sandstones vary in composition from clean quartzose to

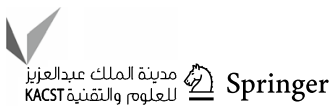



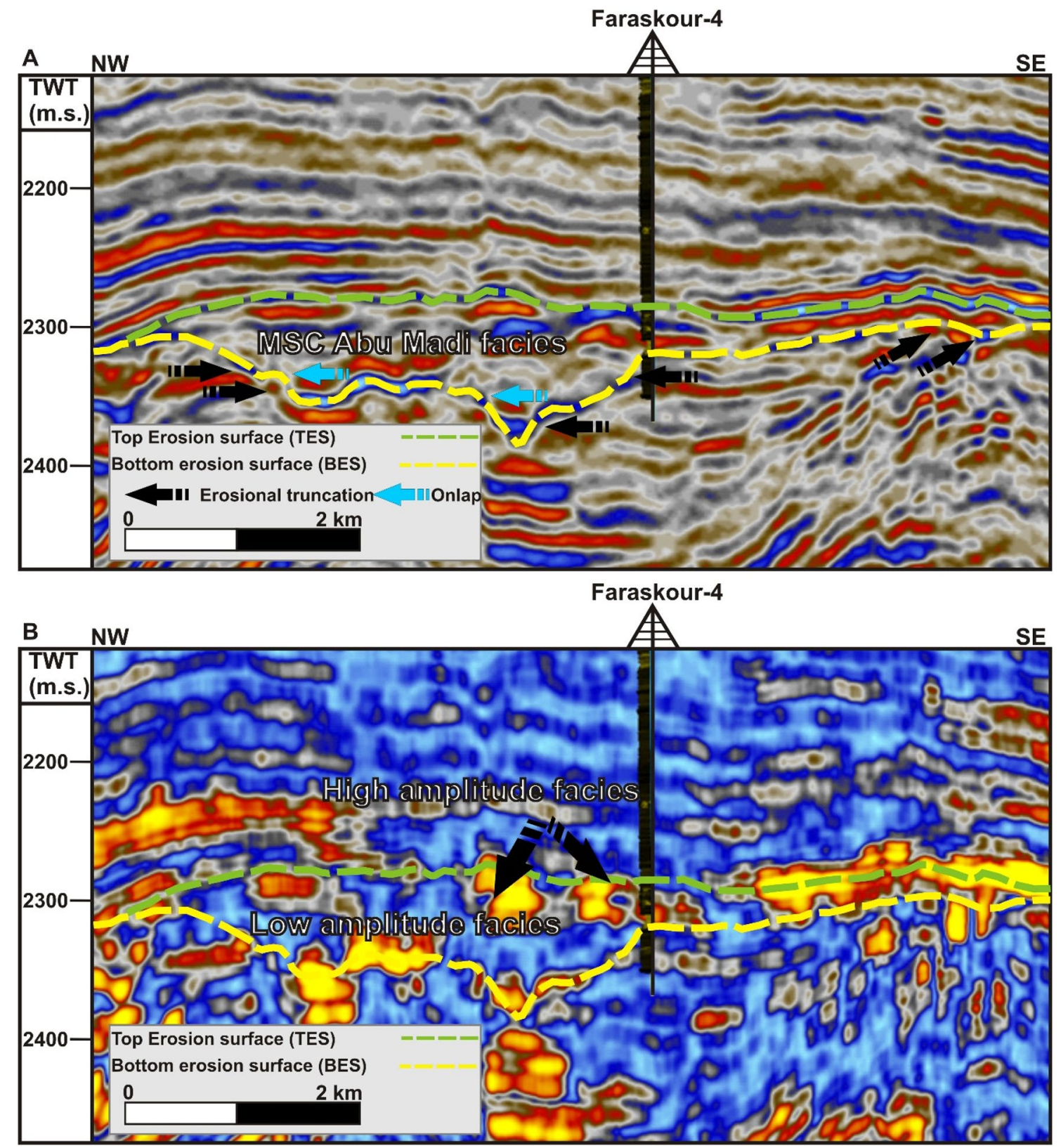

Fig. 6 Interpreted NW-SE seismic section in original amplitude (a) and RMS amplitude attribute (b) showing scattered high-amplitude bar features at the upper part of Abu Madi canyon-infill succession (see location in Fig. 1)

glauconitic and argillaceous sandstones. The quartzose sandstones are dominated by quartz (average (Av.) 65\%) and comprise approximately $60 \%$ of the Abu Madi fluvial facies (Fig. 8). They consist mainly of detrital quartz grains with subordinate quantities of K-feldspars and lithic fragments (Fig. 9a) and therefore range in composition from quartz arenite and subarkose arenite microfacies. The quartz framework grains are rounded to sub-rounded, ranging from illsorted to moderately sorted and very fine- to coarse-grained. The lithic fragments are mainly granitic; sedimentary lithics (e.g., carbonate, claystone) are also present (Fig. 9b).
Detrital clay matrix and glauconite pellets occur in minor quantities. Authigenic cements consist mainly of euhedral microcrystalline quartz overgrowth (Fig. 9a). Quartzose sandstones show a distinctive signature on the wireline logs characterized by the lowest gamma ray $(<55$ API $)$ and matrix density (RHOMA) values $\left(>2.66 \mathrm{~g} / \mathrm{cm}^{3}\right)$ (Fig. 8).

Glauconitic sandstones comprise the glauconite-rich (Av. $>10 \%$ ) samples which constitute approximately $21 \%$ of the Abu Madi fluvial interval (Fig. 8). It is made of fineto medium-grained, sub-angular, moderately sorted detrital quartz grains with abundant pore-filling and detrital

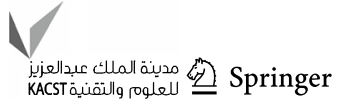




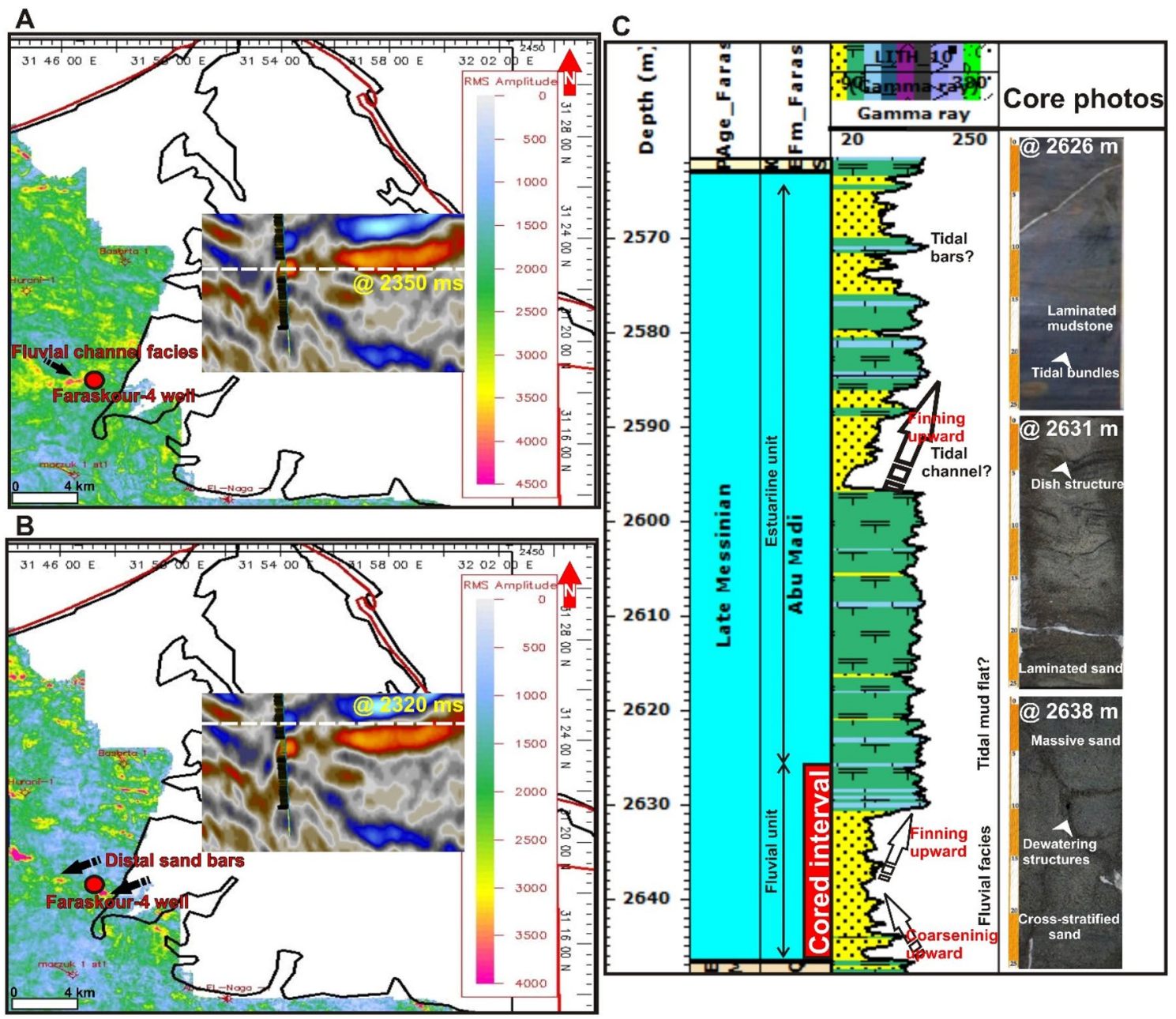

Fig. 7 Root-mean-square (RMS) amplitude maps of the Abu Madi upper reflectors. Extracted along the $2350 \mathrm{~ms}$ (a) and $2320 \mathrm{~ms}$ (b) reflections, and correlated with their corresponding core sedimentary facies $(\mathbf{c})$

glauconite (Fig. 9c, d). The glauconitic sandstones also contain subordinate quantities of bioclasts, K-feldspars as well as sedimentary lithic fragments (claystones) and are mostly classified as glauconitic subarkose arenites. Detrital clays are present as pore-filling matrix materials (Fig. 9c). Well-rounded, fine-grained glauconite pellets are very common. Pore-filling patchy glauconite is also observed in the intergranular pores. Replacive glauconite is occasionally present due to replacement of biogenic fragments and bioclasts (Fig. 9c). The abundance of wellrounded pellets as well as the common occurrence of porefilling and replacive components suggests both detrital and authigenic origin of the glauconite (e.g., Loutit et al. 1988; Amorosi and Centineo 1997; Amorosi et al. 2007). Authigenic calcite is common and is often represented by patchy pore-filling spray (Fig. 9c) and micro-spray calcite crystals around the detrital and in the dissolved framework components (Fig. 9d). On wireline logs, the glauconitic sandstones are recognized by comparatively elevated gamma ray (85-95 API) and RHOMA values $\left(2.68-2.70 \mathrm{~g} / \mathrm{cm}^{3}\right)$ (Fig. 8).

Argillaceous sandstones constitute the samples containing abundant argillaceous detrital and authigenic materials (total clays $>15 \%$ ). They comprise approximately $15 \%$ of the Abu Madi fluvial facies (Fig. 8). They are often associated with the glauconitic sandstones and consist of fine- to mediumgrained, sub-angular to rounded, moderately sorted quartz grains (Fig. 9e, f). The detrital framework components of the argillaceous sandstones also comprise fine-grained detrital glauconite pellets, bioclasts and claystone rock fragments. They are mostly classified as argillaceous quartz arenite. Detrital clay matrix is common, and clay cement comprises the most abundant authigenic phases (Fig. 9e, f). The argillaceous sandstones have distinctive gamma ray signature characterized by very high counts (>95 API) (Fig. 8).

The distinctive wireline log signatures of the studied sandstones and their robust correlation with core and petrographic observations provide a good qualitative tool to

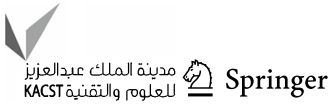


Fig. 8 Composition of the cored interval of Abu Madi fluvial sandstones and their corresponding wireline log signature

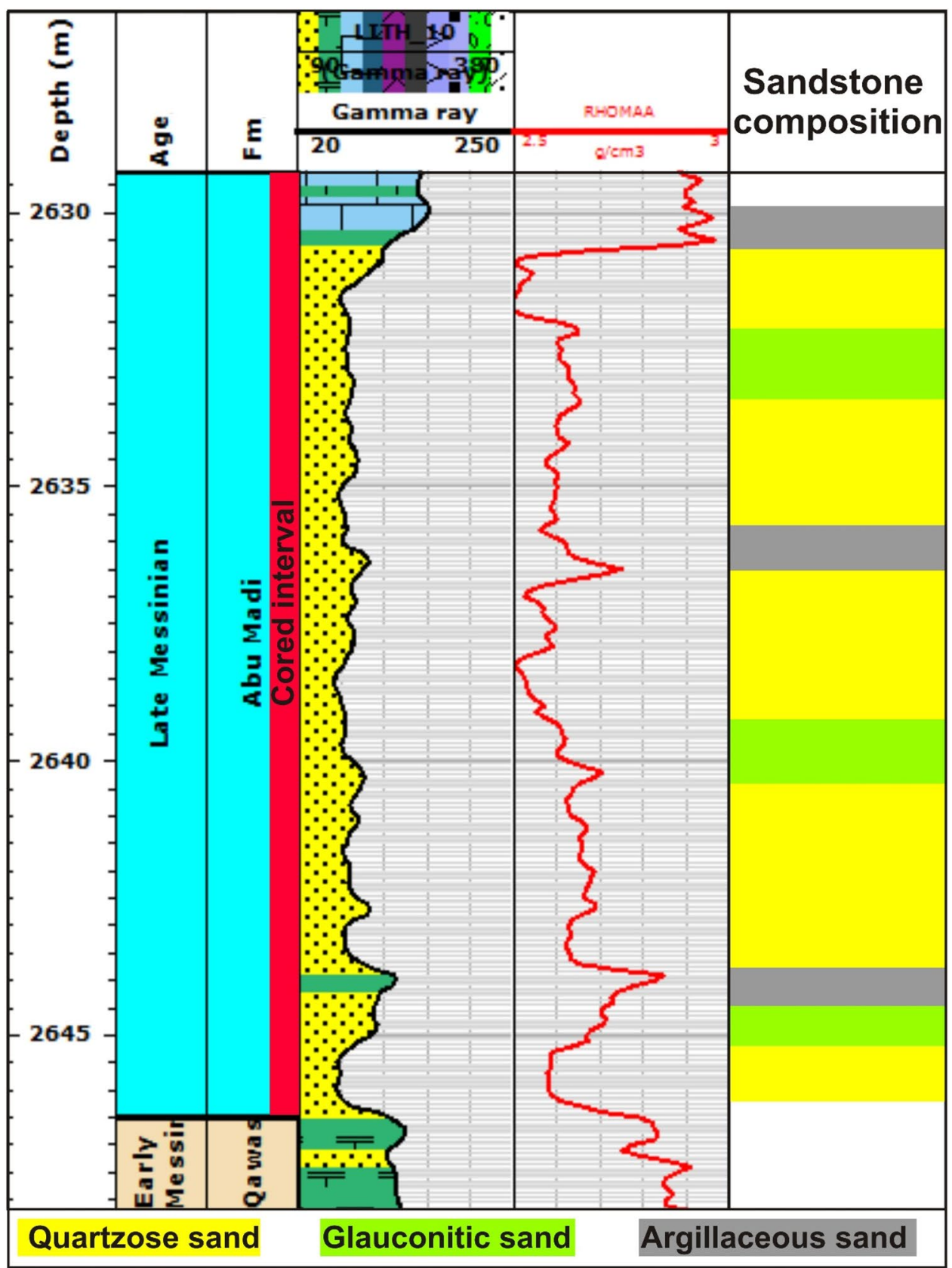

subdivide the uncored Abu Madi estuarine unit. Glauconitic sandstones constitute approximately $42 \%$ of Abu Madi estuarine sandstones (Fig. 10). The quartzose sandstones are also common and comprise about $26 \%$. They are more frequent in the upper part of the estuarine unit. Thin interbeds of argillaceous sandstones are mostly associated with the quartzose facies and constitute about $16 \%$ of the sandstone microfacies in the Abu Madi estuarine unit. Another sandstone microfacies is recorded at the base of the Abu Madi estuarine unit and is characterized by a distinctive log signature that was not observed in the underlying fluvial interval. This microfacies overlies the tidal mud flat deposits and is characterized by very low gamma ray ( $<35 \mathrm{API})$ and high matrix density values $\left(>2.9 \mathrm{~g} / \mathrm{cm}^{3}\right)$ (Fig. 10). These characteristics reveal a carbonate-rich facies and mostly coincide with the calcareous sandstones recorded at the base of the Abu Madi estuarine interval (Salem et al. 2005; Leila 2019; Leila and Moscariello 2019).

\section{Petrophysical characterization of the Abu Madi sandstones}

The measured core plug petrophysical parameters vary significantly between the studied sandstones microfacies 

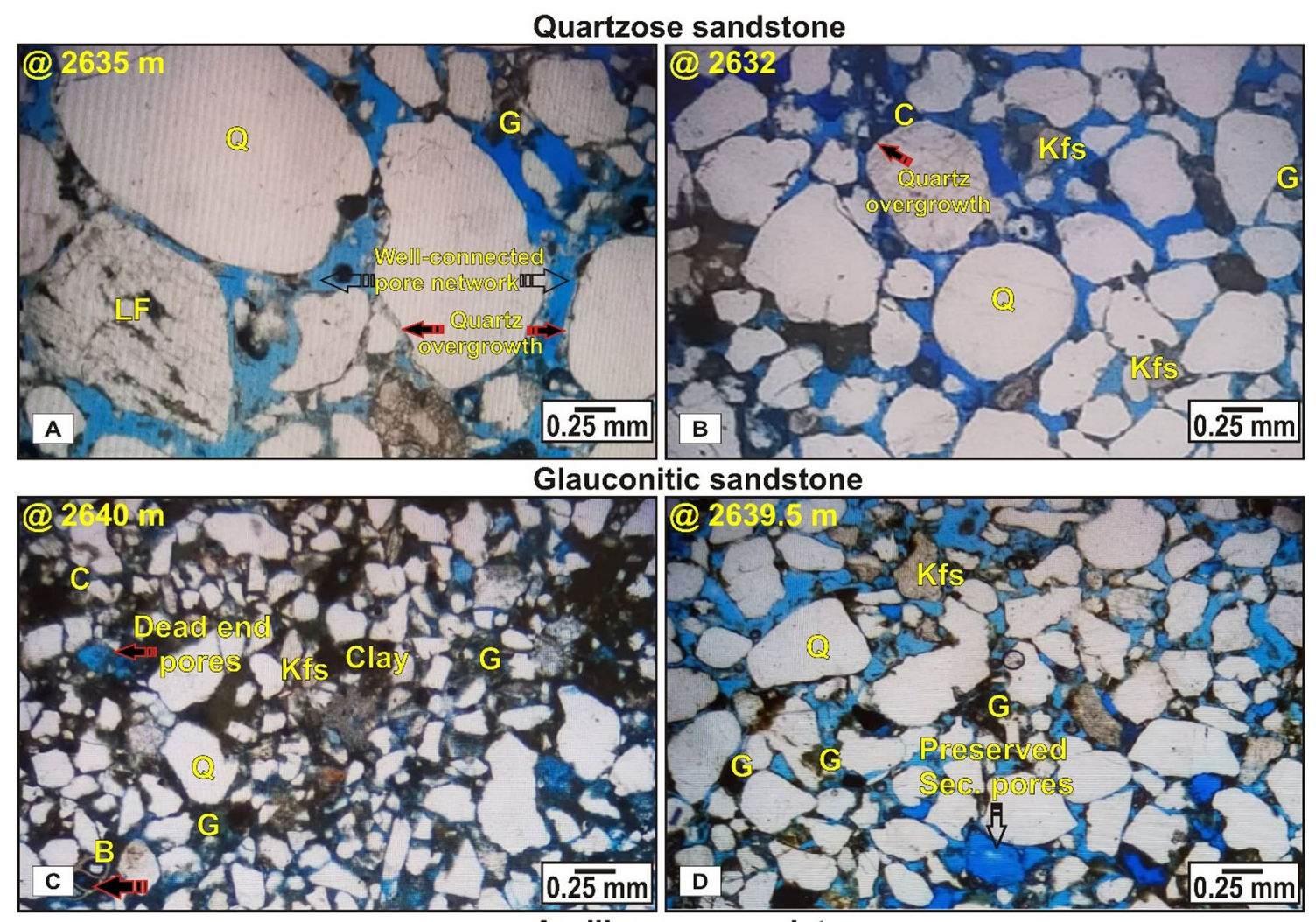

\section{Argillaceous sandstone}
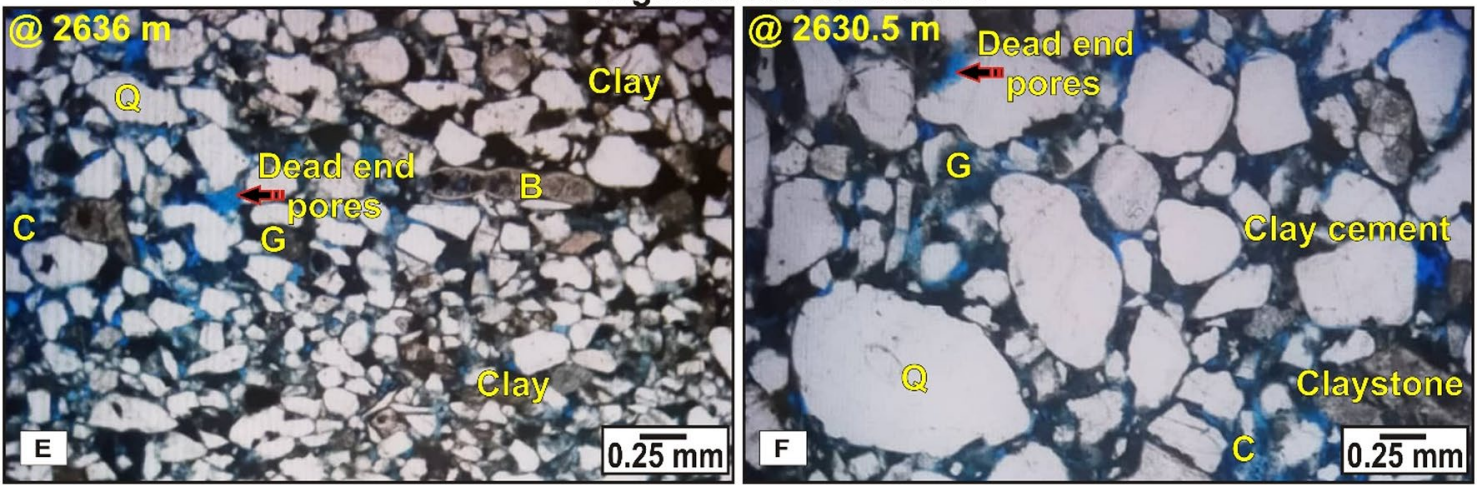

Fig. 9 Thin section microphotographs illustrating the different sandstones microfacies. Mineral symbols, quartz (Q), K-feldspar (Kfs), lithic fragments (LF), glauconite $(\mathrm{G})$, bioclasts $(\mathrm{B})$, calcite $(\mathrm{C})$, and secondary pores (Sec. pores)

(Table 1). Abu Madi quartzose sandstones constitute the highest permeability values $(\mathrm{Av} .=2958 \mathrm{md}$, Table 1$)$; however, the values vary greatly (standard deviation $(\mathrm{SD})=1468)$, typifying heterogeneous flow characteristics. The lowest permeability values are observed in the argillaceous sandstones $(\mathrm{Av} .=56.6 ; \mathrm{SD}=51.4)$. Porosity values are quite similar in the quartzose and glauconitic sandstones (Av. $=27.1 \%$ and $28 \%, \mathrm{SD}=1.4$ and 0.89 , respectively). The lowest porosity values occur in the argillaceous sandstones $($ Av. $=25.9 \%)$ and therefore characterized by the lowest storage capacity properties. The grain density also varies greatly in the studied sandstones (Table 1); the quartzose and glauconitic sandstones have similar values $\left(\mathrm{Av} .=2.64 \mathrm{~g} / \mathrm{cm}^{3}\right.$ and $2.65 \mathrm{~g} / \mathrm{cm}^{3} ; \mathrm{SD}=0.008$ and 0.03 , respectively) suggesting a dominant quartz-rich composition. On the other hand, the argillaceous sandstones have a comparatively higher values $\left(A v .=2.71 \mathrm{~g} / \mathrm{cm}^{3}\right)$ reflecting the impact of the clay matrix on the grain density readings.

The highest RQI and FZI values occur in the quartzose sandstones (Av. $=3.19$ and 8.53, respectively). The glauconitic sandstones show moderate reservoir quality characterized by good RQI and FZI values (Av. $=1.0$ and 2.55, respectively) (Table 1). The lowest RQI and FZI values 
Fig. 10 Composition of the uncored interval of Abu Madi estuarine sandstones and their corresponding wireline log signature

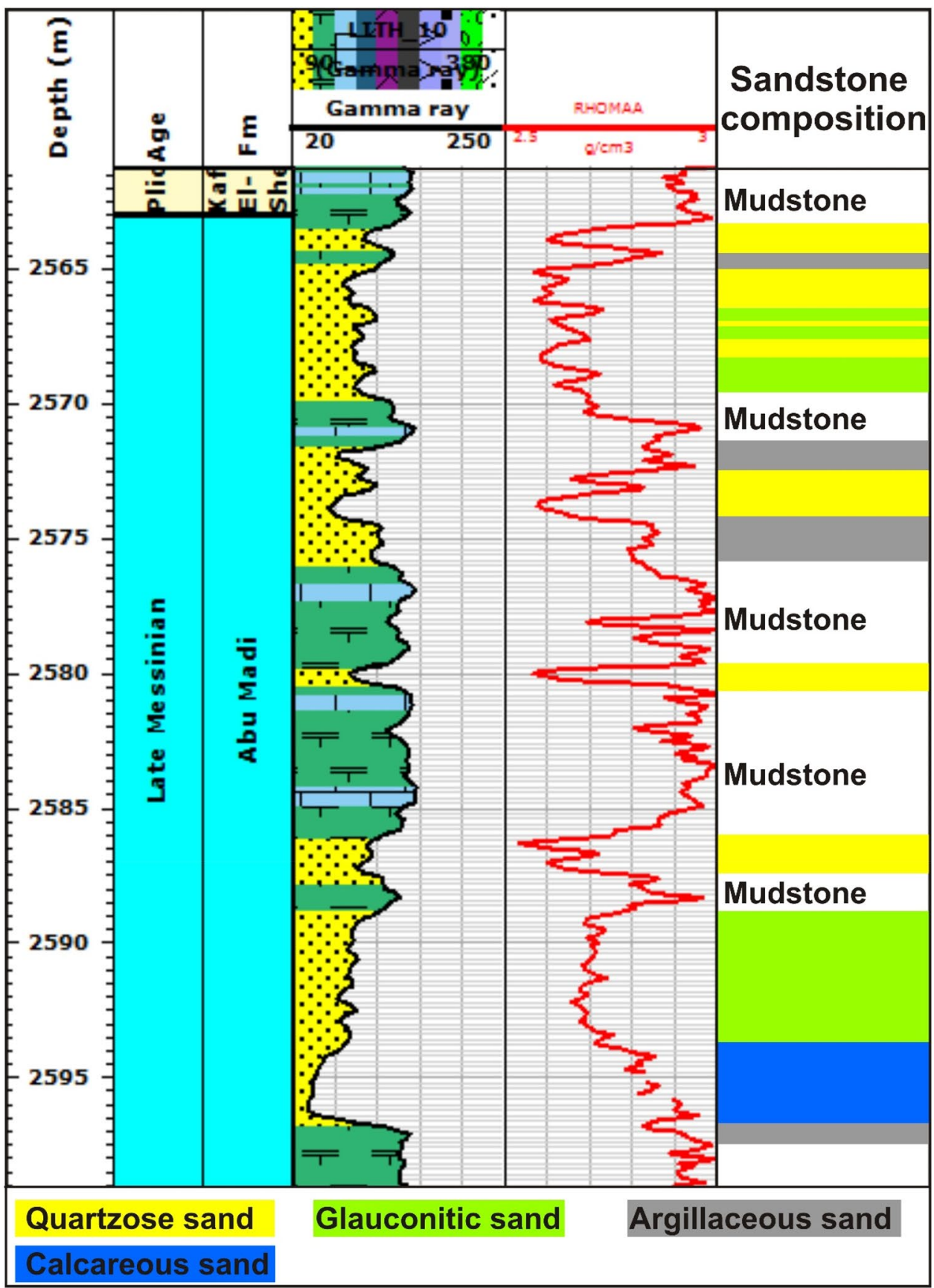

are observed in the argillaceous sandstones (Av. $=0.4$ and 1.18 , respectively), revealing their poor reservoir quality. Similarly, the calculated pore throat radius $\left(R_{35}\right)$ values are higher in the quartzose sandstones $(\mathrm{Av} .=38.03 \mu \mathrm{m})$, indicating a pore system dominated by mega pores (e.g., Kolodzie 1980; Pittman 1992). On the other hand, macropores $(\mathrm{Av} .=9.66 \mu \mathrm{m})$ and meso-pores $(\mathrm{Av} .=3.59 \mu \mathrm{m})$ are, respectively, abundant in the glauconitic and argillaceous sandstone microfacies (Table 1).

\section{Pore system characteristics}

The pore system of the Abu Madi sandstones constitutes mainly primary intergranular pores, whereas the secondary pore spaces are comparatively less common (Fig. 9). The secondary pores were mainly formed due to diagenetic dissolution of bioclasts; however, they were later filled by either authigenic calcite or glauconite (Fig. 9c). In some particular cases, authigenic microcrystalline calcite coatings preserve the secondary pore spaces. It is evident that the pore system 
Table 1 Values of the petrophysical characteristics obtained from the conventional core analysis (CCA) for the studied Abu Madi sandstones

\begin{tabular}{|c|c|c|c|c|c|c|c|c|c|c|c|c|}
\hline \multirow[t]{2}{*}{ Petrophysical parameters } & \multicolumn{4}{|c|}{ Quartzose sandstone $(n=9)$} & \multicolumn{4}{|c|}{ Glauconitic sandstone $(n=5)$} & \multicolumn{4}{|c|}{ Argillaceous sandstone $(n=4)$} \\
\hline & Min. & Max. & Av. & SD & Min. & Max. & Av. & SD & Min. & Max. & Av. & SD \\
\hline Permeability & 1358 & 5149 & 2958 & 1468 & 116 & 552 & 305 & 163 & 7.40 & 129 & 56.6 & 51.4 \\
\hline Porosity & 25.40 & 30.00 & 27.16 & 1.426 & 26.9 & 29.2 & 28 & 0.89 & 24.4 & 28.3 & 25.9 & 1.80 \\
\hline Grain density & 2.640 & 2.660 & 2.640 & 0.008 & 2.61 & 2.68 & 2.65 & 0.03 & 2.63 & 2.77 & 2.71 & 0.06 \\
\hline RQI & 2.258 & 4.313 & 3.194 & 0.756 & 0.65 & 1.39 & 1.00 & 0.27 & 0.17 & 0.69 & 0.42 & 0.21 \\
\hline NPI & 0.340 & 0.426 & 0.373 & 0.027 & 0.36 & 0.41 & 0.39 & 0.01 & 0.32 & 0.39 & 0.35 & 0.03 \\
\hline FZI & 6.182 & 11.48 & 8.531 & 1.793 & 1.77 & 3.56 & 2.55 & 0.64 & 0.52 & 1.92 & 1.18 & 0.58 \\
\hline$R_{35}$ & 25.28 & 53.83 & 38.03 & 10.30 & 5.85 & 14.1 & 9.66 & 3.03 & 1.24 & 6.31 & 3.59 & 2.08 \\
\hline
\end{tabular}

Reservoir quality index (RQI), normalized porosity index (NPI), flow zone indicator (FZI), pore throat radius $\left(R_{35}\right)$, minimum (min), maximum (max.), average (Av.) and standard deviation (SD) and number of analyzed samples (n)

of the quartzose sandstones is characterized by lowest contents of detrital clay matrix and ductile pseudomatrix materials (Fig. 9a). Similarly, authigenic minerals present minor phases except the presence of some pore-lining microcrystalline euhedral quartz overgrowth. Thereby, the primary intergranular pores are very well connected, resulting in the formation of large pore-channel network with widest pore throats (Fig. 9a).

The pore system of the glauconitic sandstones is characterized by small- to moderate-sized intergranular pore spaces. The ductile detrital glauconite pellets are commonly squeezed in the pore spaces between the ridged quartz grains forming pseudomatrix components. The pore throat of the glauconitic sandstone is mostly obstructed by both authigenic pore-filling and glauconite in the pseudomatrix (Fig. 10c, d). Consequently, the glauconitic sandstones have a comparatively narrower pore throats than the quartzose facies. However, the glauconitic sandstone intervals having low quantities of clay matrix are mostly characterized by well-connected pore system. The argillaceous sandstones contain abundant primary intergranular pore spaces. However, the pore-filling clay matrix reduces the pore throat radius, resulting in a tortoise pore system with poor pore connectivity (Fig. 10e, f). Therefore, the pore system of the argillaceous microfacies is mostly characterized by abundant isolated dead ends (Fig. 10e, f).

\section{Discussion}

\section{Petrophysical rock typing}

Four different reservoir rock types (RRT) are observed in the studied Abu Madi sandstones. These rock types have widely variable hydraulic storage (porosity) and flow (permeability) characteristics (Fig. 11a) and therefore represent different hydraulic flow units (HFU) (e.g., Bear 1972; Ebanks 1987; Amaefule et al. 1993; Table 2). RRTI has the best hydraulic flow characteristics with the highest RQI and FZI values (Table 2). RRTI hosts only quartzose sandstone samples characterized by the highest porosity and permeability values with well-connected pore-channel network (Fig. 11a). RRTI sandstones often have large and elongate pores which are mainly distributed in connected pore channels with large pore throats boosting their reservoir flow characteristics. Similarly, RRTII is also dominated by the quartzose sandstones and therefore has grain density values similar to RRTI (Fig. 11b). Both RRTI and RRTII have common mega pore spaces $(>10 \mu \mathrm{m})($ Fig. $11 \mathrm{c}$, Table 2$)$ and are considered the main fluid flow conduits within the Abu Madi Formation in the study area. However, the wide variation in pore throat radius of RRTI and RRTII despite their similar grain density values (Fig. 11c, d) is mostly attributed to the variation in grain size. RRTII sandstones are often dominated by the fine-grained sediments characterized by high porosity but comparatively smaller pore throats. RRTIII and RRTIV comprise the fluid flow baffles and barriers with moderate to low storage and flow capacities (Table 2). They constitute the glauconitic and argillaceous sandstones with pore systems dominated by pore-lining glauconite and clay matrix which effectively reduced the radius of the pore throats $(<10 \mu \mathrm{m})$.

In terms of hydraulic flow properties, the RRTI and RRTII quartzose sandstones have excellent reservoir properties and flow characteristics and are considered as the main hydraulic flow conduits within the Abu Madi Formation in the study area (Fig. 12a). On the other hand, the argillaceous and glauconitic sandstones of RRTIII and RRTIV present the flow baffles and barriers. The log-log plot of RQI versus NPI typifies a set of straight lines corresponding to variable FZI ranks which reflect different classification of the hydraulic flow units (HFUs). Five HFUs have been recognized; each HFU hosts a cluster of samples having homogeneous hydraulic flow properties (Fig. 12b). HFU4 and HFU5 have the best flow properties and thereby comprise the flow conduits intervals in RRTI and RRTII sandstones. In contrast,

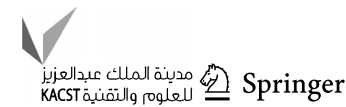



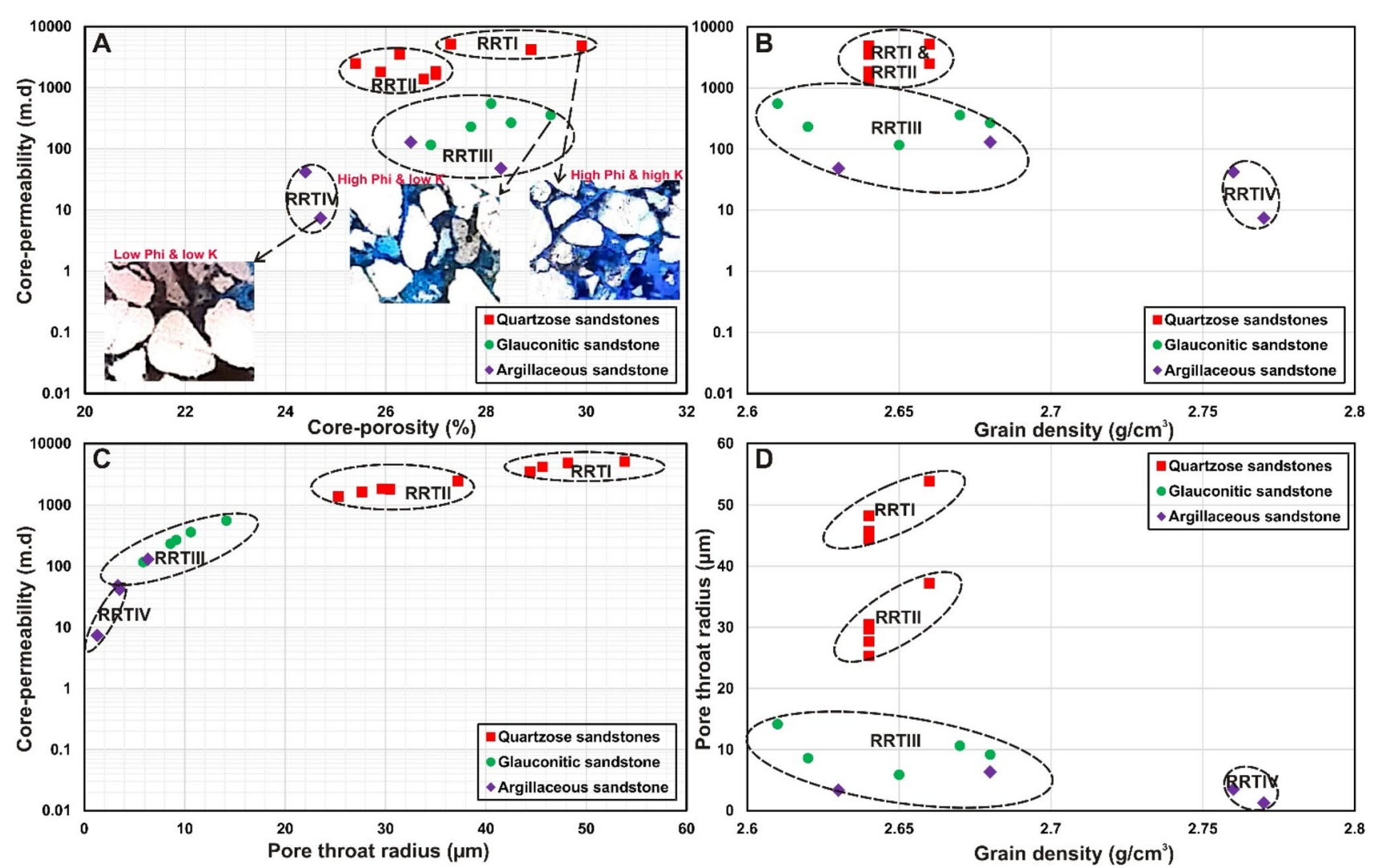

Fig. 11 Conventional core analysis (CCA) cross-plots revealing the presence of four different reservoir rock types (RRT) in the Abu Madi fluvial unit

Table 2 Quantitative petrophysical parameters for each reservoir rock type (RRT)

\begin{tabular}{lllllll}
\hline Rock type & Phi $(\%)$ & K (md) & Grain density $\left(\mathrm{g} / \mathrm{cm}^{3}\right)$ & RQI & FZI & $\begin{array}{l}\text { Pore throat } \\
\text { radius }(\mu \mathrm{m})\end{array}$ \\
\hline RRTI & $>27$ & $>3000$ & $2.64-2.66$ & $>3.5$ & $>9$ & $>45$ \\
RRTII & $25-27$ & $1000-3000$ & $2.64-2.66$ & $2-3.5$ & $6-8$ & $25-40$ \\
RRTIII & $>26$ & $100-1000$ & $2.60-2.7$ & $1-2$ & $2-4$ & $5-15$ \\
RRTIV & $<25$ & $<100$ & $>2.75$ & $<1$ & $<2$ & $<5$ \\
\hline
\end{tabular}

the flow baffles and barriers are classified as HFU3, HFU-2 and HFU-1 and therefore host the argillaceous and glauconitic sandstones of RRTIII and RRTIV. The variation in flow properties is largely contributed to the pore throat characteristics. Notably, the flow conduits (RRTI, RRTII) have a pore system dominated by megapores, whereas the pore system of the flow baffles and barriers (RRTIII, RRTIV) is dominated by meso- and micropores (Fig. 12c, d).

The same reservoir rock types are also retrieved from the wire line log responses for the Abu Madi fluvial interval (Fig. 13a, b). The four different rock types are clearly observed on the log-derived porosity and permeability cross-plot. RRTI sandstones have porosity values above $20 \%$ and permeability values exceeding $1000 \mathrm{md}$; RRTII sandstones display lower poro-perm values and, however, display comparatively elevated $\mathrm{V}_{\mathrm{Sh}}$ (shale volume) and $\mathrm{S}_{\mathrm{w}}$ (water saturation) values (Table 3 ) and mostly constitute the fine-grained quartzose sand intervals. Additionally, RRTIII and RRTIV sandstones have the lowest porosity and permeability and, however, display the highest $\mathrm{V}_{\mathrm{sh}}$ and $\mathrm{S}_{\mathrm{w}}$ values (Table 3). RRTI and RRTII constitute, respectively, $26 \%$ and $39 \%$ of the Abu Madi fluvial unit. On the other hand, RRTIII comprises 19\% and RRTIV constitutes $15 \%$ of the Abu Madi fluvial succession. Accordingly, the Abu Madi fluvial unit being dominated by RRTI and RRTII sandstones hosts the main fluid flow conduits and is therefore considered as the most prospective reservoir target in the study area. On the other side, RRTI sandstones are not recorded in the Abu Madi estuarine interval which contains only three reservoir rock types RRTII, RRTIII 

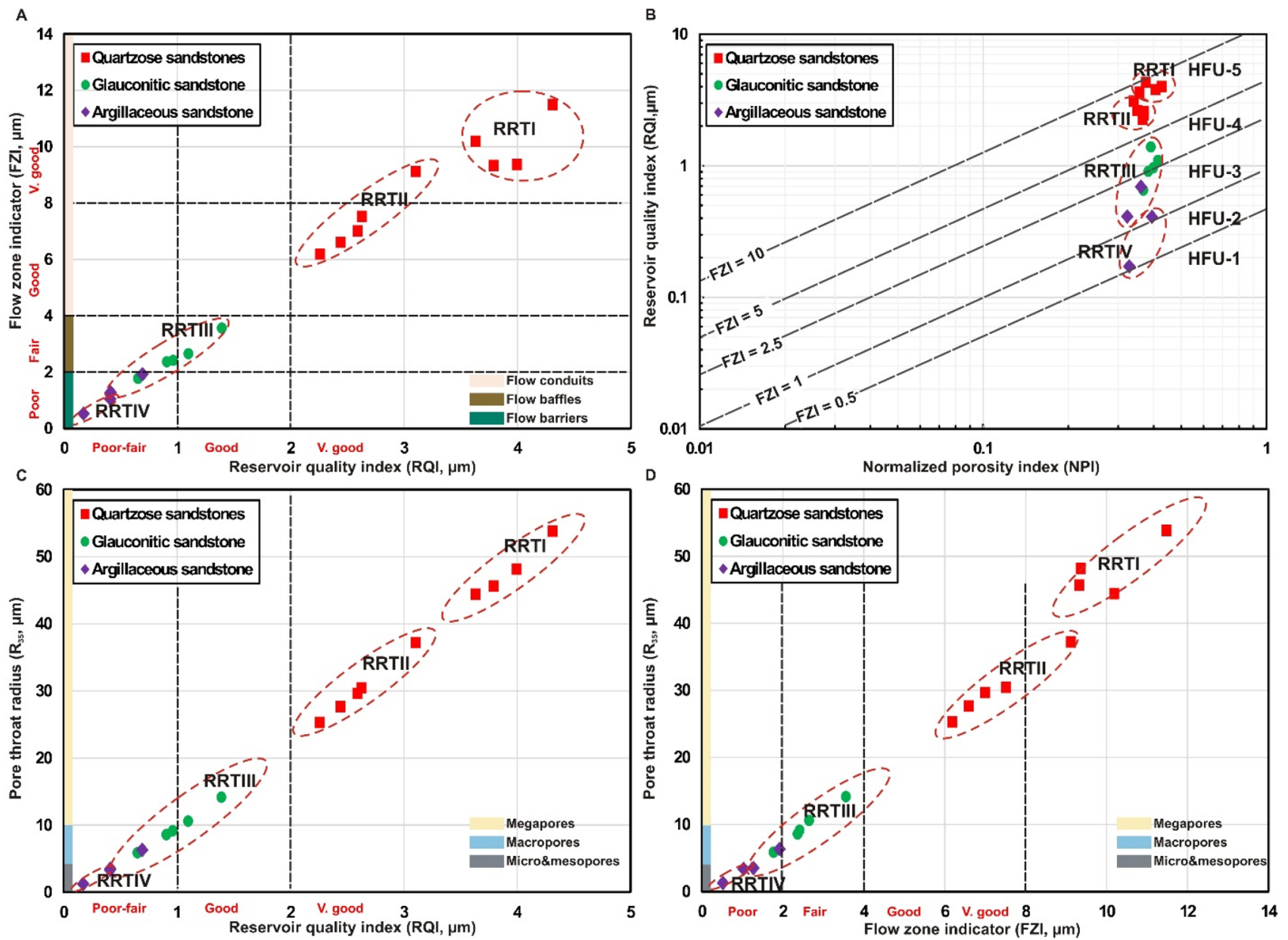

Fig. 12 a Reservoir rock typing (RRT) classification of the Abu Madi sandstones based on their reservoir quality and flow characteristics, b $\log -\log$ plot of normalized porosity index (NPI) versus reservoir quality index (RQI) illustrates the different hydraulic flow units (HFUs) encountered in the studied sandstone intervals, $\mathbf{c}$ reservoir

quality index (RQI) versus pore throat radius cross-plot illustrates abundant megapores in RRTI and RRTII sandstones, whereas mesoand micropores are dominant in RRTIII and RRTIV sediments, d flow zone indicator (FZI) versus pore throat radius cross-plot typifies the pore system and fluid flow characteristics of each RRT

and RRTIV (Fig. 14a, b). The quartzose sandstones in the estuarine unit are mostly classified as RRTII characterized by permeability values lower than $1000 \mathrm{md}$ and wide range of grain density values $\left(2.55-2.95 \mathrm{~g} / \mathrm{cm}^{3}\right)$ suggesting their heterogeneous pore system with abundant fine-grained materials. Similar to the fluvial succession, the glauconitic and argillaceous sandstones have the characteristics of RRTIII and RRTIV rocks. In addition, the calcareous sandstones were plotted with the RRTIV rocks, indicating their poor fluid storage and flow characteristics due to the abundance of pore-filling carbonate cements which completely block the pore network (Fig. 14a, b). Quantitatively, the fluid flow baffles and barriers (RRTIII and RRTIV) constitute approximately $74 \%$ of the Abu Madi estuarine sandstone unit revealing its poor potentiality as a target for future exploration in the Nile Delta.

\section{Capillary characteristics of the Abu Madi reservoir rock types}

Capillary pressure results show that the RRTI sandstones have the lowest irreducible water saturation values $\left(S_{\text {wir }}<10 \%\right)$ which increase steadily from RRTI to RRTIV (Fig. 15a). The high $S_{\text {wir }}$ values of RRTIV sandstones are mostly attributed to their elevated clay matrix and cement contents, resulting in a poor connected pore system dominated by dead end pores (Fig. 9e, f). Elevated $S_{\text {wir }}$ values in RRTIV sandstones result in increasing their initial displacement pressure, thus decreasing the hydrocarbon flow efficiency within the pore system, and thereby the hydrocarbons cannot displace the pore-water at low pressure values (e.g., Jennings 1987). Additionally, the characteristics of the "gas-water two-phase co-flowing zone" in the 

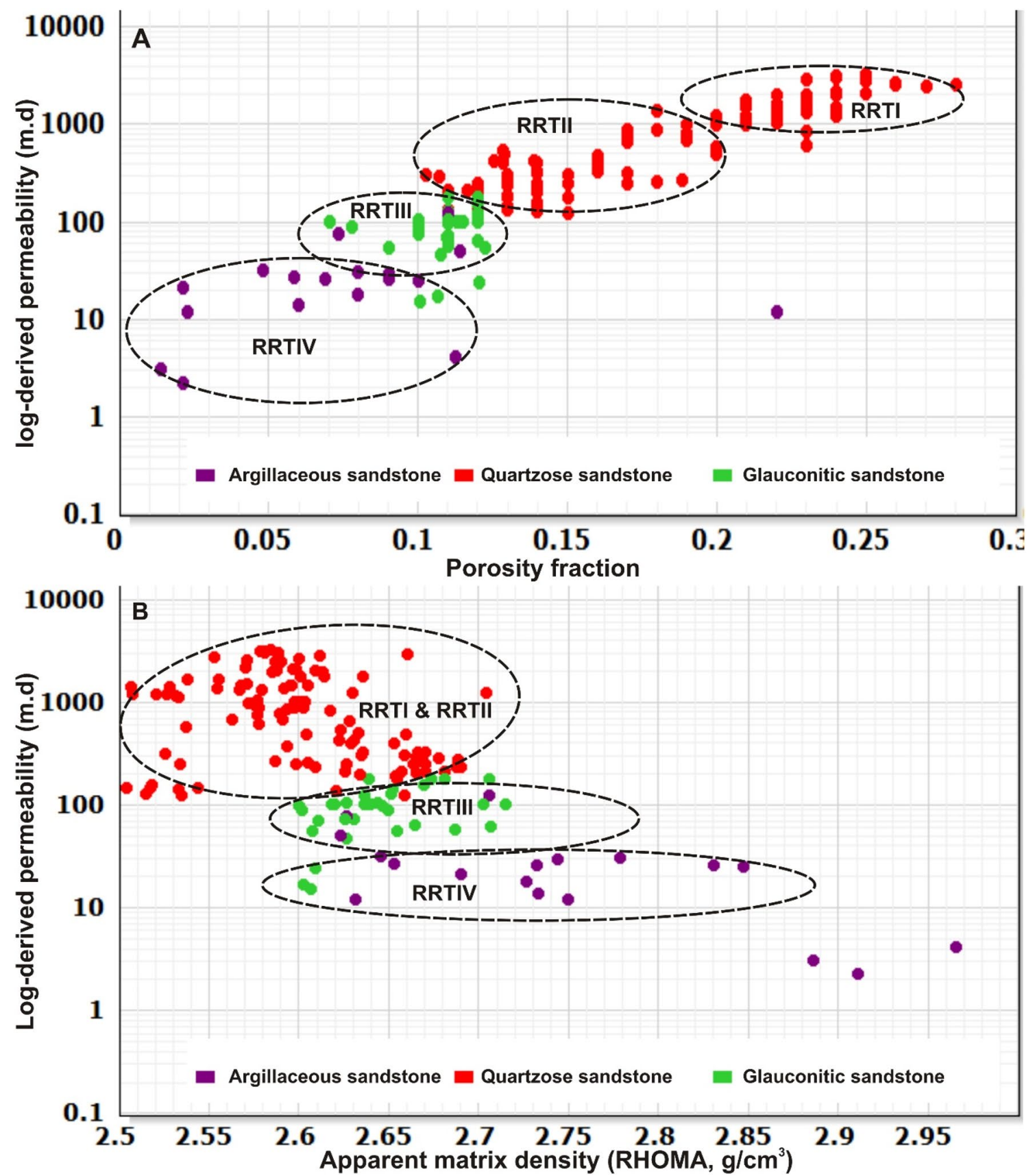

Fig. 13 Cross-plots of wireline log-derived petrophysical parameters illustrate four different RRT in the Abu Madi fluvial unit similar to the results retrieved from core analyses

Table 3 Cutoff values for each reservoir rock type (RRT) based on the results retrieved from wire line logging interpretation

\begin{tabular}{llllll}
\hline Rock type & Phi (fraction) & K $(\mathrm{md})$ & RHOMA $\left(\mathrm{g} / \mathrm{cm}^{3}\right)$ & VSh (fraction) & Sw (fraction) \\
\hline RRTI & $>0.2$ & $>1000$ & $2.5-2.66$ & $>0.25$ & $>0.3$ \\
RRTII & $0.1-0.2$ & $100-1000$ & $2.5-2.7$ & $0.25-0.4$ & $0.3-0.5$ \\
RRTIII & $0.07-0.12$ & $30-100$ & $2.60-2.75$ & $0.4-0.6$ & $0.5-0.7$ \\
RRTIV & $0-1$ & $<30$ & $2.55-2.95$ & $>0.6$ & $>0.7$ \\
\hline
\end{tabular}



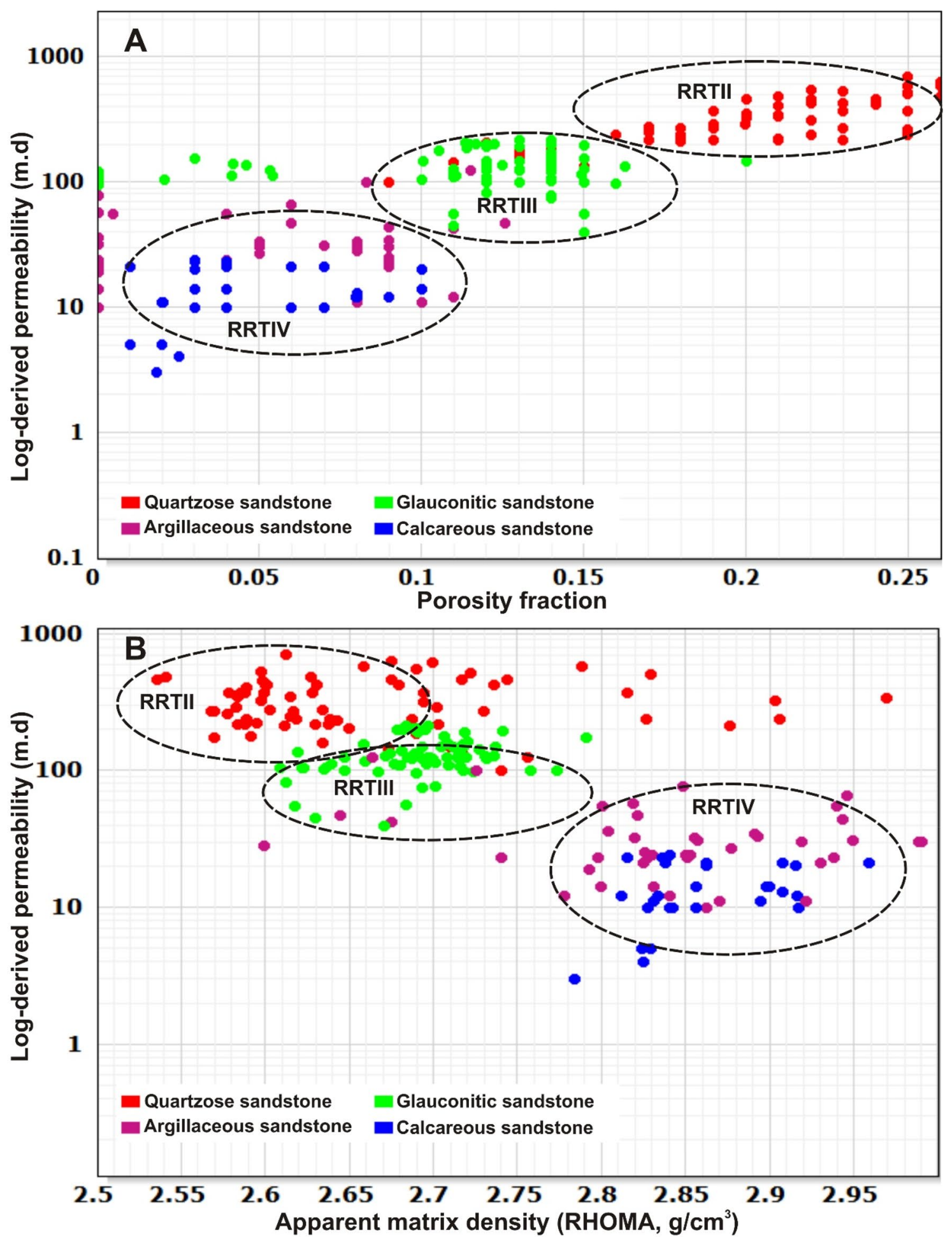

Fig. 14 Cross-plots of log-derived petrophysical parameters for the Abu Madi estuarine unit showing the absence of the best reservoir quality RRTI

relative permeability curve reveal that the co-flowing area is $\mathrm{RRTI}>\mathrm{RRTII}>\mathrm{RRTIII}>\mathrm{RRTIV}$, the $\mathrm{Krg}=\mathrm{Krw}$ point value of RRTI sandstones is the highest $(>0.9)$, whereas RRTIV rocks have the lowest ( 0.4) (Fig. 15b). The relative permeability results show that the RRTI sandstones have the lowest water wetting characteristics; and the intensity of water wetting steadily increases from RRTI to RRTIV. This behavior is mostly due to the abundance of dead 

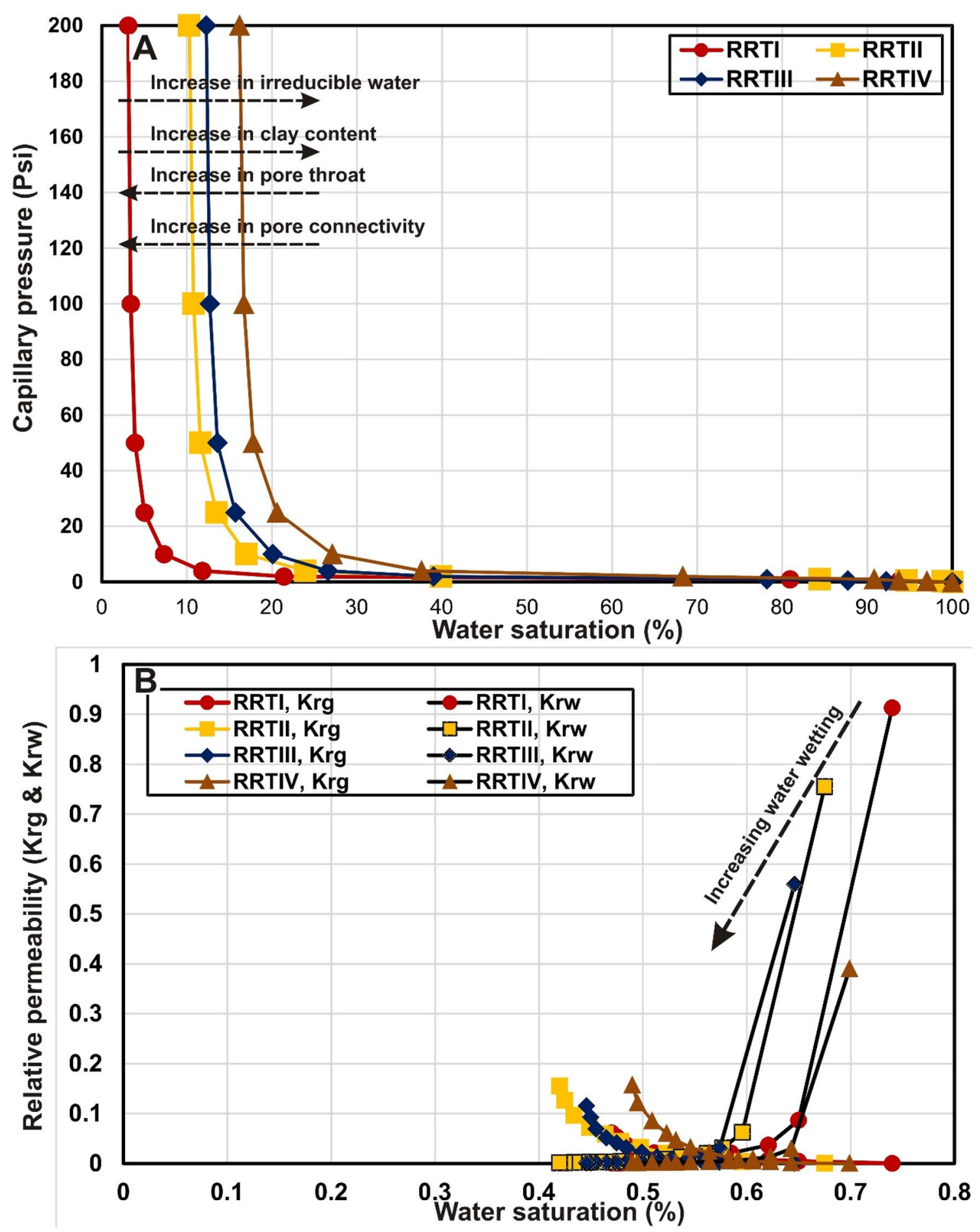

Fig. 15 Water saturation versus capillary pressure (a) and gas, water relative permeability (b) illustrating the variations in fluid flow characteristics and pore system within the different reservoir rock types

end pores in the RRTIII and RRTIV rocks (Fig. 9c, e). It is therefore obvious that the pore structure heterogeneity results in an increase in the irreducible water saturation and decrease in the movable fluid saturation (e.g., Wang et al. 2019). It is clear that RRTI sandstones have the best gas flow characteristics and its Krw at the critical gas saturation is approximately 0.9 , which means that the gas will still be able to flow in RRTI sandstones even at high water saturation values exceeding $90 \%$ (Fig. 15b). On the other hand, Krw at the critical gas saturation is 0.4 for RRTIV 

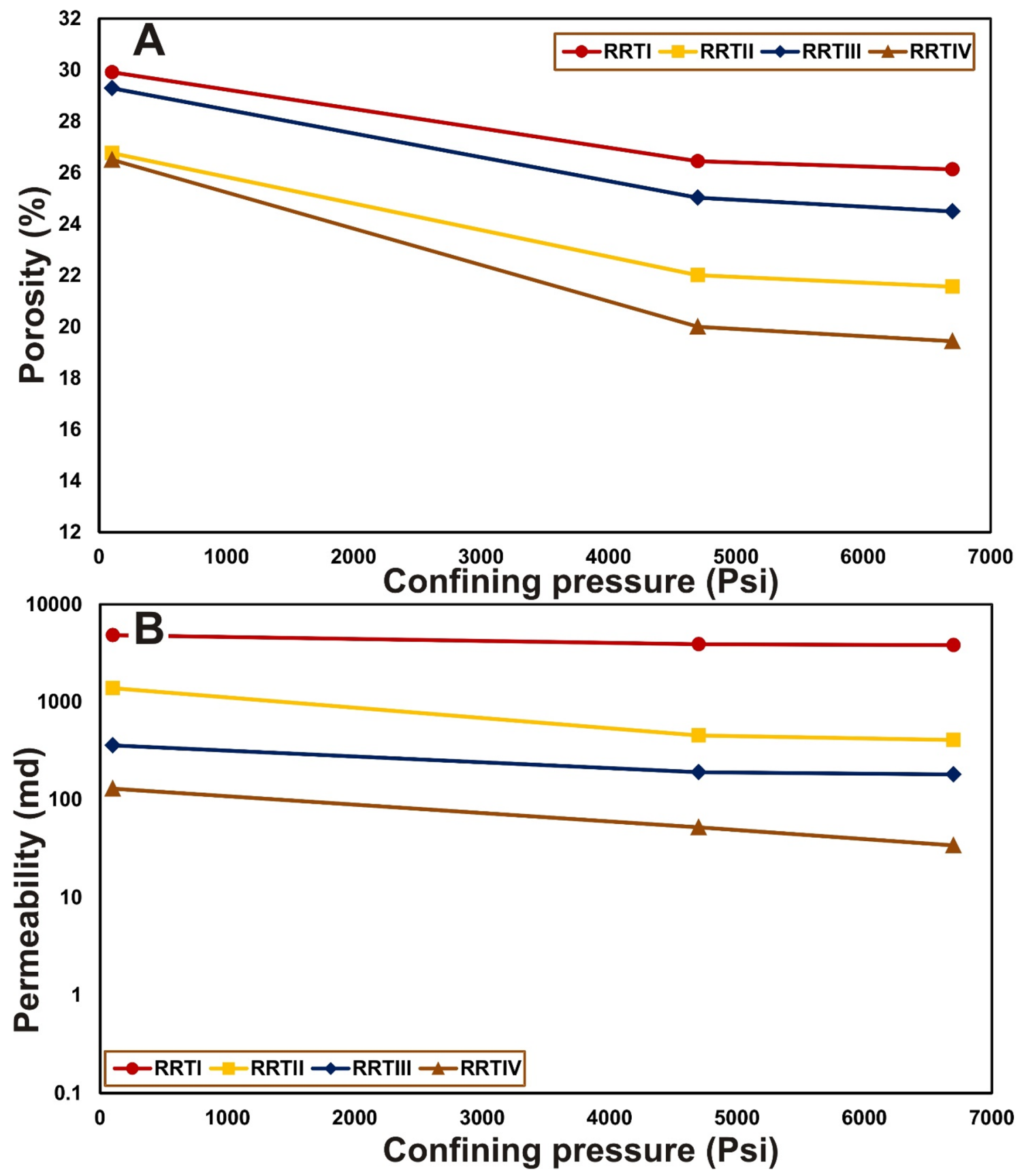

Fig. 16 Effect of confining pressure on porosity (a) and permeability (b) of the investigated reservoir rock types (RRT)

sandstones, indicating that the gas will lose its flow capacity at $40 \%$ water saturation.

\section{Impact of confining pressure on poro-perm properties}

The impact of confining pressure on porosity increases from RRTI to RRTIV facies (Fig. 16a). RRTI sandstones are the most resistant to porosity and permeability destruction up on compaction (Fig. 16b). The impact on permeability of confining pressure is very small in RRTI facies, indicating that the connectivity of the pore system remained unaffected under elevated confining pressure values. The change in pore volume under the effect of confining pressure is the highest for RRTIV sandstones which lose approximately $7 \%$ of its original porosity under 4700 psi confining stress (Fig. 17a). On the other side, the RRTI sandstones only lose $3 \%$ of its porosity under the same confining stress. This is mainly attributed to the composition of RRTI sandstones dominated by rigid quartz grains 


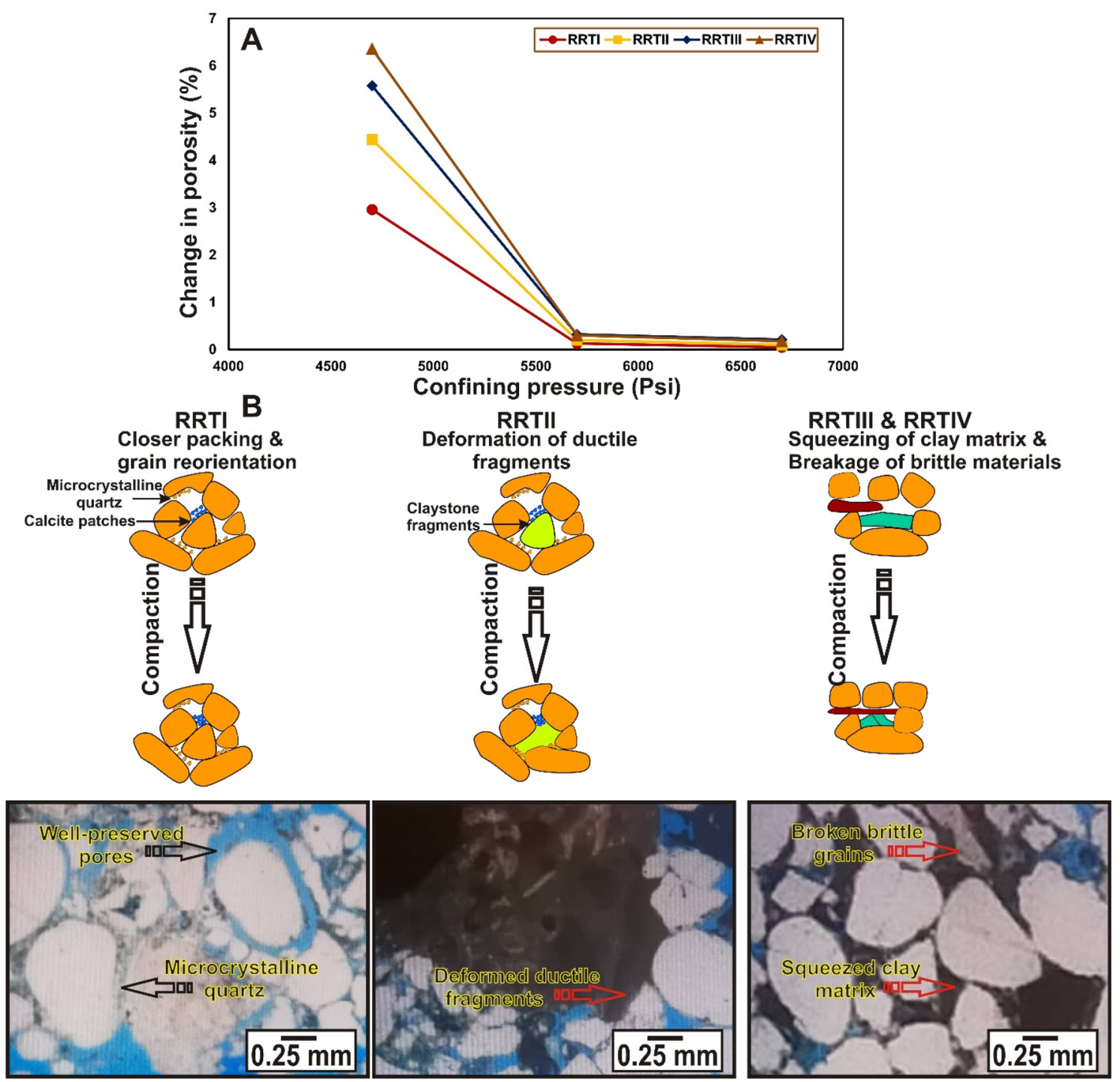

Fig. 17 a Impact of confining pressure on the pore volume of the studied RRT, b illustrative drawings and thin sections illustrating the different responses of each RRT to the confining stress

as well as microcrystalline quartz coatings which support the facies framework strength against compaction (e.g., Jonas and McBride 1977; Leila et al. 2018; Fig. 17b). In contrast, the ductile fragments (e.g., claystone) in RRTII sandstones (Fig. 9b) are squeezed in the pore spaces, resulting in a significant decrease in porosity $(\sim 4.5 \%)$ upon compaction (Fig. 17b). Similarly, the brittle platy materials (e.g., clays), ductile clay matrix and glauconite pellets in RRTIII and RRTIV facies are squeezed and broken between the rigid framework grains upon compaction, resulting in a wide porosity reduction $(\sim 5.5-6.5 \%)$ (Fig. 17b). Accordingly, RRTI sandstones have a good potentiality for primary porosity preservation and therefore will not lose their excellent flow characteristics even at great burial depths.

\section{Conclusions}

- The Abu Madi Formation in the study area constitutes two main units. The lower is dominated by fluvial sandstones deposited as amalgamated channel sand bars, whereas the upper interval mostly contains finergrained, muddy-rich estuarine sandstones.

- The Abu Madi fluvial unit consists mainly of quartzose sandstones, whereas the estuarine interval hosts abundant glauconitic and argillaceous sandstones.

- The quartzose sandstones have the highest porosity and permeability values with an isotropic pore system dominated by well-connected pore channels. On the other hand, the glauconitic and argillaceous samples have a 
highly tortoise pore system dominated by micro- and meso-sized dead ends.

- Four reservoir rock types (RRTI, RRTII, RRTIII, and RRTIV) were identified in the studied intervals. Quartzose sandstones are mainly classified as RRTI and RRTII rocks; and RRTIII and RRTIV mostly host the glauconitic and argillaceous sandstone microfacies.

- The Abu Madi fluvial unit hosts the highest thickness of RRTI rocks; in contrast, RRTIII and RRTIV predominate in the estuarine interval.

- RRTI and RRTII rocks have the best fluid flow properties (Phi, K, RQI, FZI, and $R_{35}$ ) and are characterized by well-connected pore system with very low irreducible water saturation.

- RRTIII and RRTIV have the worst fluid flow properties with pore system dominated by dead end pores and therefore contain high percentage of irreducible water.

- Confining pressure has a greater impact on the RRTIII and RRTIV sandstones, whereas the RRTI sandstones have a larger potentiality for primary porosity preservation and therefore remain the most potential reservoir targets even at elevated burial depths.

Acknowledgements The authors wish to thank the Egyptian General Petroleum Corporation (EGPC) and Wastani Petroleum Company, Egypt, for providing the data and materials that were necessary for the completion of this research. We are also grateful to Schlumberger for granting access to academic license of Petrel and Technology software.

Funding The author(s) received no specific funding for this work.

\section{Compliance with ethical standards}

Conflict of interest The authors want to declare that they do not have any conflict of interests to disclose.

Open Access This article is licensed under a Creative Commons Attribution 4.0 International License, which permits use, sharing, adaptation, distribution and reproduction in any medium or format, as long as you give appropriate credit to the original author(s) and the source, provide a link to the Creative Commons licence, and indicate if changes were made. The images or other third party material in this article are included in the article's Creative Commons licence, unless indicated otherwise in a credit line to the material. If material is not included in the article's Creative Commons licence and your intended use is not permitted by statutory regulation or exceeds the permitted use, you will need to obtain permission directly from the copyright holder. To view a copy of this licence, visit http://creativecommons.org/licenses/by/4.0/.

\section{References}

Abdel Aal A, Price R, Vital J, Sharallow J (1994) Tectonic evolution of the Nile delta, its impact on sedimentation and hydrocarbon potential. In: Proceedings of 12th EGPC exploration and production conference, Cairo, Egypt, vol 1, pp 19-34

Amaefule J, Altunbay M, Tiab D, Kersey D, Keelan D (1993) Enhanced reservoir description, using core and log data to identify hydraulic (flow) units and predict permeability in uncored intervals/wells. In: SPE 26436, annual technical conference and exhibition, Houston, TX, pp 3-6

Amorosi A, Centineo MC (1997) Glaucony from the Eocene of the Isle of Wight (southern UK), implications for basin analysis. Geol Soc Lond 154:887-896

Amorosi A, Sammartino I, Tateo F (2007) Evolution patterns of glaucony maturity, A mineralogical and geochemical approach. Deep Sea Res Part II Top Stud Oceanogr 54:1364-1374

Archie G (1942) The electric resistivity logs as an aid in determining some reservoir characteristics. Trans Am Int Mech Eng 146:54-62

Barber P (1981) Messinian subaerial erosion of the proto-Nile Delta. Mar Geol 44:253-272

Bayoumi A, Lotfy H (1989) Modes of structural evolution of Abu Gharadig Basin, Western Desert of Egypt, as deduced from seismic data. J Afr Earth Sci 9:273-287

Bear J (1972) Dynamics of fluids in porous media. American Elsevier Publishing Company, New York, p 764

Buatois L, Mángano M, Carr T (1999) Sedimentology and ichnology of Paleozoic estuarine and shoreface reservoirs, Morrow Sandstone, Lower Pennsylvanian of southwest Kansas, USA. Kansas Geological Survey Bulletin 243. Current Research Earth Science

Clauzon G, Rubino J, Savoye B (1995) Marine Pliocene Gilberttype fan deltas along the French Mediterranean coast. Atypical infill feature of preexisting subaerial Messinian canyons. IAS Reg. Met. Sed., Field trip Guide book. Publ., A.S.F, vol 23, pp $145-222$

Corex (2007) Sedimentological and petrographic analyses on the cored Abu Madi Formation from Mansoura Concession, onshore Nile Delta, Egypt. (Unpublished Internal Reports)

Dabrio C, Polo M (1995) Oscilaciones eustáticas de alta frequencia en el Neógeno superior de Sorbas (Almería, sureste de España). Geogaceta 18:75-78

Dalla S, Hamed H, Serrazi M (1997) Hydrocarbon exploration in a complex incised valley fill, An example from the late Messinian Abu Madi Formation (Nile Delta Basin, Egypt). Leading Edge, pp 1819-1824

Dixon J, Robertson A (1984) The geological evolution of the eastern mediterranean. Geological Society of London, Spec. Publ., vol 17

Dolson C, Shaan V, Matbouly S, Harwood C, Rashed R, Hammouda H (2001) The petroleum potential of Egypt. In:Downey W, Threet C, Morgan A (eds) Petroleum provinces of the twenty-first century. AAPG, vol 74, pp 453-482

Dolson JC, Boucher PJ, Siok J, Heppard P (2005) Key challenges to realizing full potential in an emerging giant gas province, Nile Delta/Mediterranean offshore, deep water, Egypt. In: Doré A, Vining B (eds)Petroleum geology, north-west Europe and global perspectives, Geological Society of London, Petroleum Geology Conference Series no. 6, Proceedings of 6th petroleum geology conference, pp 607-624

Ebanks W Jr (1987) Flow unit concept-integrated approach to reservoir description for engineering projects. AAPG. Bull. 71:551-552

EGPC (Egyptian General Petroleum Corporation) (1994) Nile Delta and North Sinai, Field discoveries and hydrocarbon potentials (A comprehensive overview). EGPC, Cairo, p 387

El-Diasty W, Peters K, Moldowan J, Essa G, Hammad M (2020) Organic geochemistry of condensates and natural gases in the northwest Nile Delta offshore Egypt. J Petrol Sci Eng 187:106819 
Esestime P, Hewitt A, Hodgson N (2016) Zohr: a newborn carbonate play in the Levantine Basin, East-Mediterranean. First Break 34:87-93

Guiraud R, Bosworth W (1999) Phanerozoic geodynamic evolution of northeastern Africa and the northwestern Arabian platform. Tectonophysics 315:73-104

Harms J, Wray J (1990) Nile Delta. In: Said R (ed) The Geology of Egypt. Balkema, Rotterdam, pp 329-344

Houghton H (1980) Refined techniques for staining plagioclase and alkali feldspar in thin section. J Sed Petrol 50:629-631

Hsü KJ, Cita MB, Ryan WBF (1973) The origin of the Mediterranean evaporites. In: Kaneps A (ed) Leg 13, Initial Reports of the Deep Sea Drilling Project, vol 13, no. 2, pp 1203-1231

Hussein I, Abd-Allah A (2001) Tectonic evolution of the northeastern part of the African continental margin, Egypt. J Afr Earth Sci 33:49-69

Jennings JB (1987) Capillary pressure techniques: application to exploration and development geology. AAPG Bull 71:1196-1209

Jonas E, McBride E (1977) Diagenesis of sandstone and shale-application to exploration for hydrocarbons. AAPG, Publ. vol 1

Kamel H, Eita T, Sarhan M (1998) Nile delta hydrocarbon potentiality, Egypt. In: Proceedings of 14th EGPC exploration and production conference Cairo, Egypt, vol 1, pp 485-503

Klein G (1971) A sedimentary model for determining paleotidal range. Geol Soc Am Bull 82:2585-2592

Kolodzie S (1980) Analysis of pore throat size and use of the WaxmannSmits equation to determine OOIP in Spindle Field, Colorado. In: Proceedings society of petroleum engineers, 55th annual technical fall conference SPE-9382

Krijgsman W, Fortuin A, Hilgen F, Sierro F (2001) Astrochronology for the Messinian Sorbas basin (SE Spain) and orbital (precessional) forcing for evaporite cyclicity. Sed Geol 140:43-60

Leila M (2019) Clay minerals distribution in the pre-, syn-Messinian salinity crisis sediments of the onshore Nile Delta, Egypt, Mineral origin and implications on the reservoir quality. J Afr Earth Sci 154:35-48

Leila M, Moscariello A (2017) Organic geochemistry of oil and natural gas in the West Dikirnis and El-Tamad fields onshore Nile Delta, Egypt, Interpretation of potential source rocks. J Petrol Geol 40:37-58

Leila M, Moscariello A (2019) Seismic stratigraphy and sedimentary facies analysis of the pre- and syn-Messinain salinity crisis sequences, onshore Nile Delta, Egypt, Implications for reservoir quality prediction. Mar Petrol Geol 101:303-321

Leila M, Kora M, Ahmed M, Ghanem A (2016) Sedimentology and reservoir characterization of the upper Miocene Qawasim Formation, El-Tamad oil field onshore Nile Delta, Egypt. Arab J Geosci 9:1-13

Leila M, Moscariello A, Šegvić B (2018) Geochemical constraints on the provenance and depositional environment of the Messinian sediments, onshore Nile Delta, Egypt, Implications for the late Miocene paleogeography of the Mediterranean. J Afr Earth Sci 143:215-241

Leila M, Moscariello A, Šegvić B (2019) Depositional facies controls on the diagenesis and reservoir quality of the Messinian Qawasim and Abu Madi formations, onshore Nile Delta, Egypt. Geol J 54:1797-1813

Leila M, Moscariello A, Kora M, Mohamed A, Samankassou E (2020) Sedimentology and reservoir quality of a Messinian mixed siliciclastic carbonate succession, onshore Nile Delta, Egypt. Mar Petrol Geol 112:104076

Lofi J, Gorini C, Berne S, Clauzon G, Dos Reis A, Ryan W, Steckler M (2005) Erosional processes and paleo-environmental changes in the Western Gulf of Lions (SW France) during the Messinian Salinity Crisis. Mar Geol 217:1-30

Lofi J, Deverchere J, Gaullier V, Gillet H, Guennoc P, Gorini C, Loncke L, Maillard A, Sage F, Thinon I (2011a) Seismic Atlas of the "Messinian Salinity Crisis" Markers in the Mediterranean and Black Seas.
Geological French Society, World Geological Map Commission, Paris, $\mathrm{p} 72$

Lofi J, Sage F, Deverchere J, Loncke L, Maillard A, Gaullier V, Thinon I, Gillet H, Guennoc P, Gorini C (2011b) Refining our knowledge of the Messinian salinity crisis records in the offshore domain through multi-site seismic analysis. La Soc Geol Fr 182:163-180

Loutit T, Hardenbol J, Vail P, Baum G (1988) Condensed sections, the key to age determinations and correlation of continental margin sequences. In: Wilgus C, Hasting B, Kendall C, Posamentier H, Ross C, Van Wagoner J (eds) Sea level changes, an integrated approach, SEPM Spec. Publ., vol 42, pp 183-213

Meshref WM (1990) Tectonic framework of Egypt, In: Said R (ed) The geology of Egypt, A. A. Balkema/Rotterdam/Brookfield, pp $113-156$

Miall A (1996) The geology of fluvial deposits: sedimentary facies, basin analysis and petroleum geology. Springer, Berlin, p 582

Orwig E (1982) Tectonic framework of northern Egypt and the eastern Mediterranean regime. EGPC 6th Exploration Seminar, Egypt

Palmieri G, Harby H, Martini J, Hashem F, Dalla S, Shash M (1996) Baltim Fields complex, an outstanding example of hydrocarbon accumulations in a fluvial Messinian incised valley. In: Proceedings of 13th EGPC exploration and production conference Cairo, Egypt, vol 1, pp 256-269

Pigott JD, Abdel-Fattah M (2014) Seismic stratigraphy of the Messinian Nile Delta coastal plain, Recognition of the fluvial Regressive Systems Tract and its potential for hydrocarbon exploration. J Afr Earth Sci 25:9-21

Pigott JD, Radivojevic D (2010) Seismic Stratigraphic Based Chronostratigraphy (SSBC) of the Serbian Banat Region of the Basin (Pannonian Basin). Cent Eur J Geosci 2(4):481-500

Pittman E (1992) Relationship of porosity and permeability to various parameters derived from mercury injection-capillary pressure curves for sandstone. AAPG Bull 76:191-198

Rizzini A, Vezzani F, Coccocetta V, Milad G (1978) Stratigraphy and Sedimentation of Neogene-Quaternary section in the Nile Delta area, (A.R.E). Mar Geol 27:327-348

Said R (1990) The geology of Egypt. A. Balkema Publishers, New York, p 734

Salem M (1976) Evolution of the Eocene-Miocene sedimentation pattern in northern Egypt. AAPG 60:34-64

Salem AM, Ketzer JM, Morad S, Rizk RR, Al-Aasm IS (2005) Diagenesis and reservoir-quality evolution of incised valley sandstones, evidence from the Abu Madi gas reservoirs (Upper Miocene), the Nile Delta Basin, Egypt. J Sed Res 75:572-584

Sarhan M, Hemdan K (1994) North Nile Delta structural setting trapping and mechanism, Egypt. In: Proceedings of 13th EGPC exploration and production conference, Cairo, Egypt, vol 1, pp 1-18

Schlumberger (1974) Log Interpretation. Volume II, Application, Schlumberger Ltd., New York

Sestini G (1995) Egypt. In: Kulke H (ed) Regional Petroleum Geology of The World, Part II, Africa, America, Australia and Antarctica (Beiträge zur regionalen Geologie der Erde 22. Gebrüder Borntraeger Verlagsbuchhandlung, Stuttgart, pp 66-87

Terwindt J (1971) Litho-facies of inshore estuarine and tidal-inlet deposits. Geol Mijnbouw 50(3):515-526

Timur A (1968) An Investigation of permeability, porosity, \& residual water saturation relationships for sandstone reservoirs. The Log Analyst IX, 4, SPWLA-1968-vIXn4a2

Tucker M (2001) Sedimentary petrology. Blackwell Scientific, Oxford, p 272

Vail PR, Mitchum RM Jr, Thompson S III (1977) Seismic stratigraphy and global changes in sea level, part four, global cycles of relative changes of sea level. AAPG Mem 26:83-98

Van den Berg J, Boersma J, Van Gelder A (2007) Diagnostic sedimentary structures of the fluvial-tidal transition zone- evidence from deposits of the Rhine and Meuse. Neth J Geosci 86:306-387 
Vandre C, Cramer B, Gerling P, Winsemann J (2007) Natural gas formation in the western Nile Delta (Eastern Mediterranean), thermogenic versus microbial mechanisms. Org Geochem 38:523-539

Wang M, Yang Z, Shui C, Yu Z, Wang Z, Cheng Y (2019) Diagenesis and its influence on reservoir quality and oil-water relative permeability, a case study in the Yanchang Formation Chang 8 tight sandstone oil reservoir, Ordos Basin, China. Open Geosci 11:37-47 